\title{
Field evidence for the lateral emplacement of igneous dykes: Implications for 3D mechanical models and the plumbing beneath fissure eruptions
}

\author{
David Healy ${ }^{\star \alpha}$, Roberto E. Rizzo ${ }^{\alpha, \beta}$, Marcus Duffy ${ }^{\alpha}$, \\ Natalie J. C. Farrell ${ }^{\alpha}$, Malcolm J. Hole ${ }^{\alpha}$, David Muirhead ${ }^{\alpha}$ \\ ${ }^{\alpha}$ School of Geosciences, University of Aberdeen, Aberdeen AB24 3UE, United Kingdom \\ $\beta$ Research Complex at Harwell, Rutherford Appleton Laboratory, University of Manchester, Didcot OX11 0FA, United Kingdom
}

\begin{abstract}
Seismological and geodetic data from modern volcanic systems strongly suggest that magma can be transported significant distance (tens of kilometres) in the subsurface away from central volcanic vents. Geological evidence for lateral emplacement preserved within exposed dykes, sills and inclined sheets includes aligned fabrics of vesicles and phenocrysts, striations on wall rocks, measurements of anisotropic magnetic susceptibility and geometrical features such as steps and bridges. In this paper, we present geometrical evidence for the lateral emplacement of segmented dykes restricted to a narrow depth range (few tens of metres) in the crust. Near-total exposure of three dykes on wave cut platforms around Birsay (Orkney, UK) are used to map out floor and roof contacts of neighbouring dyke segments in relay zones. The field evidence suggests emplacement from the WSW towards the ENE, and that the dykes are segmented over their entire vertical extent. Geometrical evidence for the lateral emplacement of segmented dykes is likely more robust than inferences drawn from flow-related fabrics, due to the occurrence of ubiquitous "drainback" events (i.e. magmatic flow reversals) observed in modern systems.
\end{abstract}

Keywords: Magma; Relay; Bridge; Segment; Igneous; Volcanic

\section{INTRODUCTION}

\subsection{Background}

Igneous dykes are the frozen remnants of magma conduits and preserve evidence of major Earth processes such as magma transport from mantle to crust and the rifting of continents and oceans [Burchardt 2018]. Our understanding of dyke emplacement has been driven by field observations [e.g. Johnson 1961; Delaney and Pollard 1981; Gudmundsson 1983; Ryan 1988; Ágústsdóttir et al. 2016], analogue and numerical modelling [e.g. Galland et al. 2006; Kavanagh et al. 2018; Maccaferri et al. 2011] and physical theories of fracture mechanics, fluid dynamics and heat flow [e.g. Rubin 1995; Rivalta et al. 2015; Townsend et al. 2017]. Threedimensional (3D) models of dyke nucleation, propagation and arrest are in their infancy, and our current understanding remains rooted in two-dimensional (2D) models [Kavanagh et al. 2018; Pollard and Townsend 2018; Rivalta et al. 2015; Townsend et al. 2017]. Magma derived from the mantle must undergo a significant vertical component of movement to be emplaced in the upper crust. However, the specific emplacement direction immediately before the magma solidifies is vari-

${ }^{*}$ Corresponding author: d.healy@abdn.ac.uk able [e.g. Poland et al. 2008]. Previous workers have documented significant sub-horizontal components of magma flow and dyke emplacement direction based on some combination of evidence from: flow fabrics in either the solid matrix or the vesicles and amygdales, palaeomagnetic signals from dyke margins, and seismicity [e.g. Ernst and Baragar 1992; Staudigel et al. 1992; Poland et al. 2008; Townsend et al. 2017]. In relation to emplacement directions, the geometrical form of segmented dykes has received relatively little attention (but see Rickwood [1990] and Magee et al. [2018]). This paper describes three well-exposed segmented dykes in Orkney (UK) and uses their geometrical form in outcrop to infer the likely direction of dyke emplacement.

The dominant paradigm for explaining the geometry of en echelon dyke segments has been based on a diagram in Delaney and Pollard [1981] (Figure 1). The exposed discrete segments are believed to root down into a continuous dyke at depth. Note that a key corollary of this model is that the segment tip-lines are steeply plunging. This conceptual model is derived from a linear elastic fracture mechanics approach to dyke propagation in tensile cracks [Delaney and Pollard 1981]. Segmentation along the upper edge is due to rotation of the least principal stress during upward (i.e. vertical) propagation. However, seismological, geodetic and 


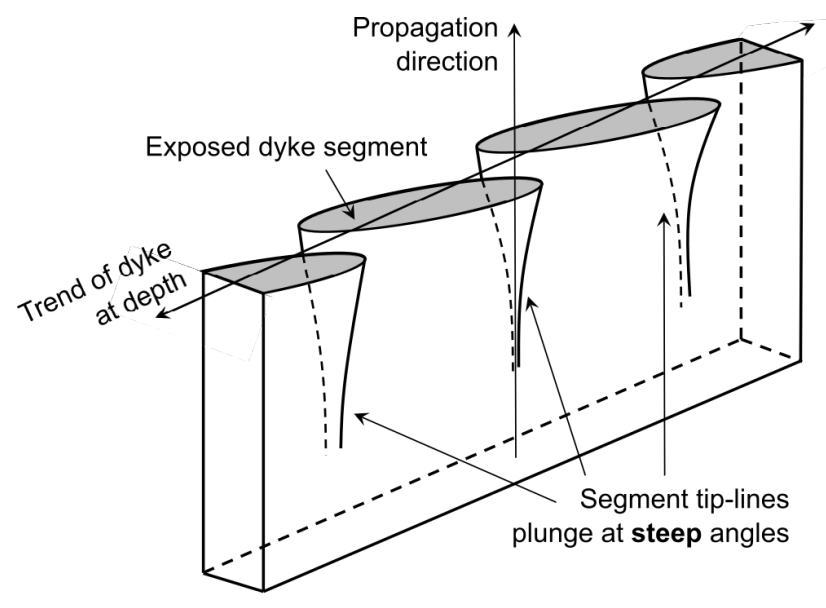

after Delaney and Pollard [1981]

Figure 1: Schematic diagram of a vertical dyke propagating upwards and divided into en echelon segments, or 'fringes', at the leading edge (after Delaney and Pollard [1981]). Note that this model implies that the margins of dyke segments at the segment tips are steeply plunging.

outcrop evidence strongly suggests that at least some dykes propagate laterally [Brandsdóttir and Einarsson 1979; Ryan 1988; Ágústsdóttir et al. 2016; Townsend et al. 2017]. Geophysical evidence from modern volcanic settings, such as Bárðarbunga-Holuhraun on Iceland and Kîlauea on Hawaii, combined with direct observations of temporal and spatial patterns in fissure eruptions, are consistent with significant (i.e. tens of kilometres) sub-horizontal migration of magma away from central vents. The location of the seismicity suggests that the migration pathways are restricted to relatively narrow depth ranges (few kilometres) in the upper crust. A mechanical basis for lateral dyke emplacement at a specific depth has been advanced by Allan M. Rubin [Rubin and Pollard 1987; Rubin 1995] and refined by Townsend et al. [2017]. Dyke emplacement will be vertically restricted when the stress intensity factors at the top and bottom tip-lines of the dykehosting crack are insufficient to overcome the fracture toughness of the host rock. Moreover, lateral propagation is favoured when the stress intensity factor at the lateral tip-line exceeds the fracture toughness of the host. Likely conditions for lateral propagation are then predicted to occur at the depth of a density contrast in the crust, for which magma density is between that of the over and underlying layers [Rubin 1995]. In modern settings, this is likely to be the interface between the volcanic pile and the underlying basement.

\subsection{Rationale}

In this paper, we present detailed field observations from a suite of three segmented dykes perfectly exposed on the foreshore at Birsay in Orkney (Scotland,
UK). We describe the geometry of the dykes in relation to the uniformly dipping sedimentary host rocks, with a particular focus on the relays —or bridges-between adjacent segments. Throughout this paper, we refer to the rock volumes around neighbouring dyke segment pairs as relays, as a direct extension of the concepts and terminology used for faults [Walsh et al. 1999]. Even though dykes (and sills) are dominated by extensional (dilatational) strains, and perhaps locally by tensile stresses, we believe the term 'relay' accurately captures the core concept of deformation (displacement, strain) being transferred, or more literally 'passed on', from one segment to another. The corollary of applying the term relay to dykes is that relays are then seen to constitute a quasi-continuous spectrum of types from those dominated by tensile stress or extensional strain (e.g. dyke, sill or vein relays), through hybrid extension + shear relays, to those dominated by shear strain or stress (e.g. fault relays). Furthermore, this leads to the inference that relays dominated by contractional strain (and/or compressive stress) may also exist, for instance in the case of stylolites or other anti-crack phenomena [Fletcher and Pollard 1981]. The terms 'bridges' (intact) and 'broken bridges' (breached) have been widely used for these dyke relay structures in the past [e.g. Jolly and Sanderson 1995; Schofield et al. 2012]. Nevertheless, we believe 'relay' (breached or unbreached) represents a better-more homologous-connection to the underlying kinematics and mechanics of brittle fracture (and filling), and provides scope for a unified understanding of deformation in the rock volumes between neighbouring en echelon fractures of any kinematics. We use the term 'step' for a short (typically a few $\mathrm{cm}$ ) lateral shift in a dyke segment where the lateral offset [sensu Rickwood 1990] is much less than the dyke thickness; i.e. the segment remains unbroken at the level of exposure.

Near perfect exposure of thinly-bedded and jointed rocks on the wave cut platforms at Birsay has been exploited using high-resolution photo-mosaics captured by a camera mounted on an Unmanned Aerial Vehicle (UAV, or drone). Using these orthorectified photomosaics as a base, we systematically collected observations and measurements from segment relay zones for all three dykes. These field observations, captured as digital photographs, orientation data, and field notebook sketches, form the basis for the interpretations of 3D relay geometry. In the following sections, we describe the location and regional context for the dykes, and their host rocks, and then present a summary of petrological observations. The focus then shifts to the detailed geometries of the dyke segment relays, with observations followed by interpretations of the 3D structure. We then discuss the issues arising from our model for the Birsay dykes, and put this in the context of previous mechanical analyses and data from modern volcanic systems. 


\section{Geological setting}

The dykes at Birsay have been emplaced into Devonian rocks of the Orcadian Basin. This basin extended from Inverness in the south to Shetland in the north, and formed following the collapse of the Caledonian orogen [McClay et al. 1986]. The basin fill is dominated by cyclic lacustrine deposits towards the basin centre, and alluvial and fluvial deposits towards the margins. The sedimentary sequence at Birsay is dominated by thinly bedded $(<1$ metre) sandstones, siltstones and mudstones of Middle Devonian age, assigned to the Upper and Lower Stromness Flagstone Formations, and records shallow- and deep-water lacustrine facies, including turbidites [Andrews and Hartley 2015]. This sedimentary sequence rests unconformably on a metamorphic basement, seen further south around Stromness, correlated with Moine metasedimentary rocks of the mainland [Strachan 2003].

The dykes at Birsay are alkaline lamprophyres and have been assigned to the Permo-Carboniferous camptonite-monchiquite suite by Rock [1983]. This suite extends over much of the Scottish Highlands and Islands and comprises dykes and rare vents (plugs). Samples from dykes in Orkney and nearby Caithness on the Scottish mainland have yielded radiometric ages of $245 \pm 12 \mathrm{Ma}$ and $249-268 \pm 4$ Ma i.e. late Permian [Brown 1975; Baxter and Mitchell 1984]. These rocks form part of a widespread Permian alkaline magmatic episode extending across the North Sea to the Oslo Graben (Norway). Dykes from this suite are common in Orkney and Caithness on the Scottish mainland, and typically strike ENE. Their widths vary from a few centimetres to over one metre. Our study at Birsay focuses on three such dykes (Figure 2).

\section{Methods}

To fully exploit the near total exposure of the dykes and their host rocks at Birsay we surveyed the area with an Unmanned Aerial Vehicle mounted with a 12.4 megapixel camera (DJI ${ }^{\mathrm{TM}}$ Phantom 3 Professional). We flew repeated sorties to map the whole wave cut platform and details of selected dykes at altitudes between 5 and $15 \mathrm{~m}$ above mean sea level. Digital photographs from these flights were then merged and orthorectified into high-resolution map view mosaics using Agisoft ${ }^{\mathrm{TM}}$ Photoscan software. Ten ground control points located with a GPS were used to improve geospatial referencing of the processed image mosaics. The final mosaic has a resolution of about $1 \mathrm{~cm}$ per pixel. Sections of the final mosaic were printed on A3 paper and used as detailed basemaps for the collection of field data, such as the orientations of dyke margins, joints and bedding, and observations of changes in texture or mineralogy. We mapped three segmented dykes in detail with overall lengths of 225, 205 and 186 metres (Dykes 0 East, 1, and 2, respectively; Figure 3).
Orientation data were measured with a standard compass clinometer, with an estimated error of $\pm 1^{\circ}$ in dip or strike. Scan line data was collected using the method of Mauldon et al. [2001], using a circular template of known radius $(14.5 \mathrm{~cm})$ placed onto quasihorizontal surfaces at fixed intervals. Fracture intensity at each point is then estimated as $n / 4 r$, where $n$ is the number of fractures intersecting the circular hoop perimeter and $r$ is the radius of the hoop.

We took oriented samples from the dykes, including their margins and cores, for thin section analysis. Thin sections were analysed under a standard optical petrographic microscope and then in a Zeiss Gemini 300 scanning electron microscope (SEM) at the University of Aberdeen. We used a combination of backscattered electron (BSE) images and energy dispersive spectroscopy (EDS) to map the mineral phases and their chemical composition. We used a voltage of $15 \mathrm{kV}$ and a working distance of about $10 \mathrm{~mm}$.

\section{Observations}

\subsection{General dyke morphology and structure}

The dykes exposed at Birsay trend ENE, varying between $65^{\circ}$ to $75^{\circ}$, and dip steeply to the south at 65 $80^{\circ}$. All three dykes are composed of multiple segments at the present level of exposure (Figure 3). The dykes comprise en echelon arrays of quasi-linear segments rotated a few degrees $\left(<10^{\circ}\right)$ clockwise of the overall dyke trend. Most segments show no overlap or underlap at the relays. Offsets, measured perpendicular to dyke segment strike at the relays, vary from a few centimetres to just over one metre. Dyke segment widths decrease from WSW to ENE in all three dykes. Dyke 0 varies in width from $70 \mathrm{~cm}$ to $45 \mathrm{~cm}$. Dyke 1 varies from $45 \mathrm{~cm}$ to $25 \mathrm{~cm}$. Dyke 2 varies from $60 \mathrm{~cm}$ to $42 \mathrm{~cm}$. Most of the dyke segments are parallel sided for most of their strike length, with only local deviations to oblique margins at steps. Contacts with the host rock are generally sharp, although more diffuse margins are observed at a few segment tips. Some tips are tapered whereas others are blunt. The host rocks strike uniformly NNE/SSW and dip at a constant angle to the WNW at around 20 degrees (Figure 4). No significant rotations of bedding were seen adjacent to the dykes, with the exception of small blocks in segment relays (see below). The host rocks are cut by three sets of joints, one of which is parallel to the dyke segment margins (Figure 4). The NNE trending joint set is only weakly developed relative to the other two sets. The dykes have produced baked margins in the sedimentary host rocks, with widths (on either side) typically less than $100 \%$ of the dyke width and approximately symmetrical on both sides. Marked colour changes are apparent in the host rocks, especially in the finer grained siltstones and mudstones, from pale 


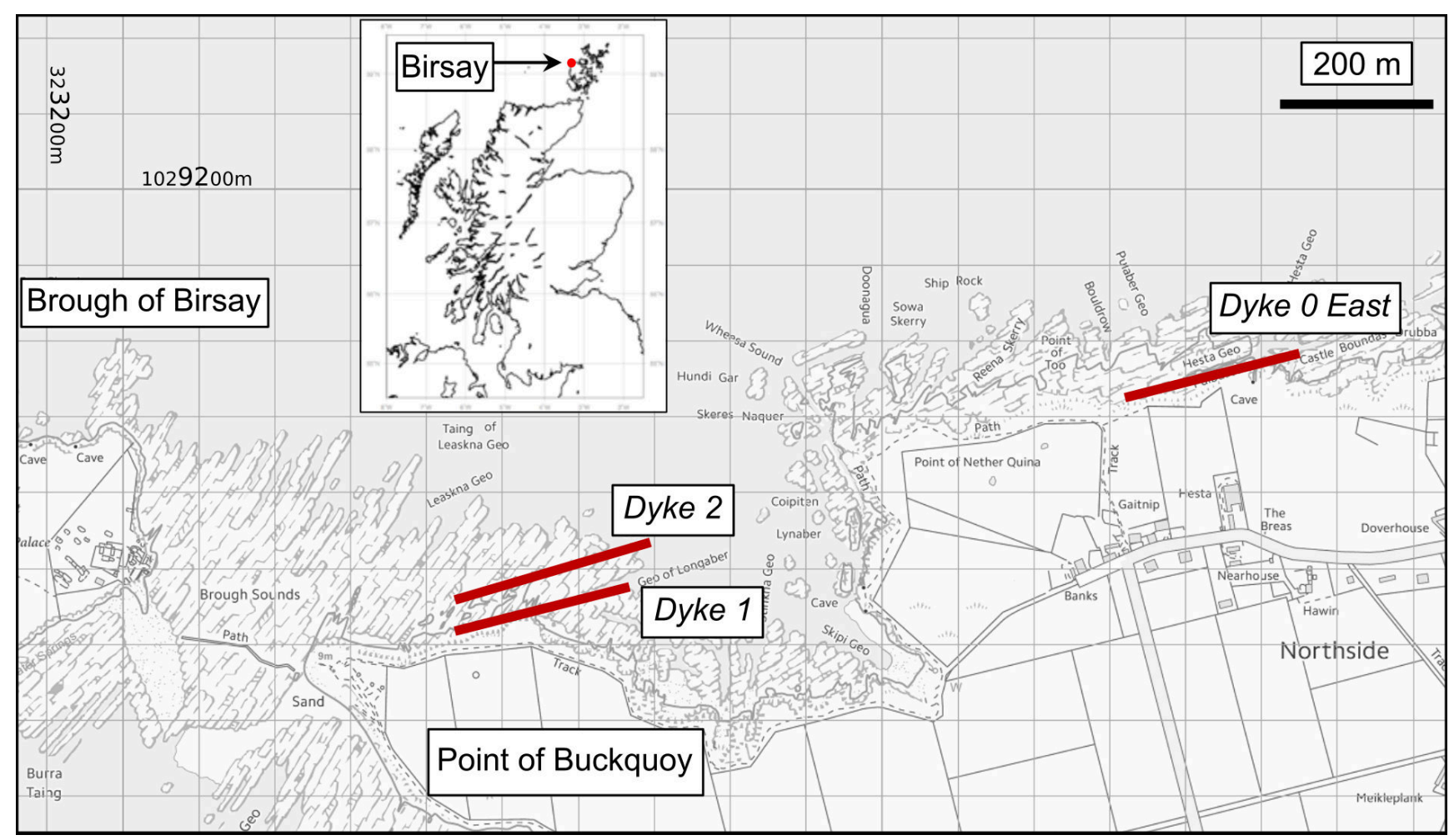

Figure 2: Details of the study area at Birsay, Orkney (UK). Inset map shows the location of Birsay at the NW corner of the Mainland of Orkney, off the north coast of Scotland. Main map shows the locations of the three dykes studied in detail in this paper. Excellent exposures are found in the wave cut platform to the north side of the Point of Buckquoy and at the top of the cliffs beyond the houses at Northside. Dyke thickness exaggerated for clarity. Note that the segmentation of these dykes is not apparent at this scale. Background Ordnance Survey map from EDINA Digimap. (C) Crown copyright and database rights 2017 Ordnance Survey (Digimap Licence).

buff-grey to much darker grey. In some cases, these are zoned with a narrow $(\sim 1-2 \mathrm{~cm})$ very dark grey zone adjacent to the margin, and then a slightly lighter grey zone ( 10-20 cm wide) outside of this.

\subsection{Dyke petrography, mineralogy and textures}

In outcrop and hand specimen, the dykes appear mafic. The weathered appearance is a medium grey, appearing darker grey on fresh surfaces. Groundmass grain size varies from glassy to medium grained. Many segments display a crude zonation, with chilled margins and a vesicular central core flanked by non-vesicular zones (Figure 5A). Chilled margins in outcrop can appear complex with very fine grained or glassy edges passing inwards to zones of mixed lighter and darker grey aphanitic rock (Figure 5B). Thin sections of samples from all three dykes confirm the presence of chilled margins and coarser porphyritic cores. The dyke segment cores contain phenocrysts of zoned augite (up to $5 \mathrm{~mm}$ ) and Ti-rich amphibole (up to $1 \mathrm{~mm}$ ) in a fine grained matrix of alkali feldspar and serpentine (after olivine). Accessory phases include Mn-rich calcite, dolomite, quartz, Cr spinel and Ni-rich pyrite (Figure $5 \mathrm{C})$. The chilled margins contain small $(\sim 10 \mu \mathrm{m})$ needles of Ti-rich amphibole set in a glassy matrix (Figure 5D).

4.3 Details of segment tips and relays between segments

In the following detailed descriptions of the segment relays, a local labelling convention is used for the segments in each relay: S1, S2, ..., Sn. These labels have no significance beyond the particular relay under discussion.

\subsubsection{Relay A - Dyke 1}

In this relay, the two neighbouring segments ( $\mathrm{S} 1$ and S2) of Dyke 1 are each approximately $45 \mathrm{~cm}$ across (see Figure $3 \mathrm{~B}$ for location). The lateral offset between the two segments is about $20 \mathrm{~cm}$ and there is no underor overlap (Figure 6A-B). At the easternmost exposed edge of S1, a shallow West dipping floor contact between the dyke above and host siltstone below can be traced for about one metre (Figure 6C-D). At the westernmost exposed edge of S2, a shallow West dipping roof contact between the dyke below and host siltstone above can also be traced for about one metre (Figure $6 \mathrm{E}-\mathrm{F})$. Both the floor of S1 and roof of S2 dip gently 

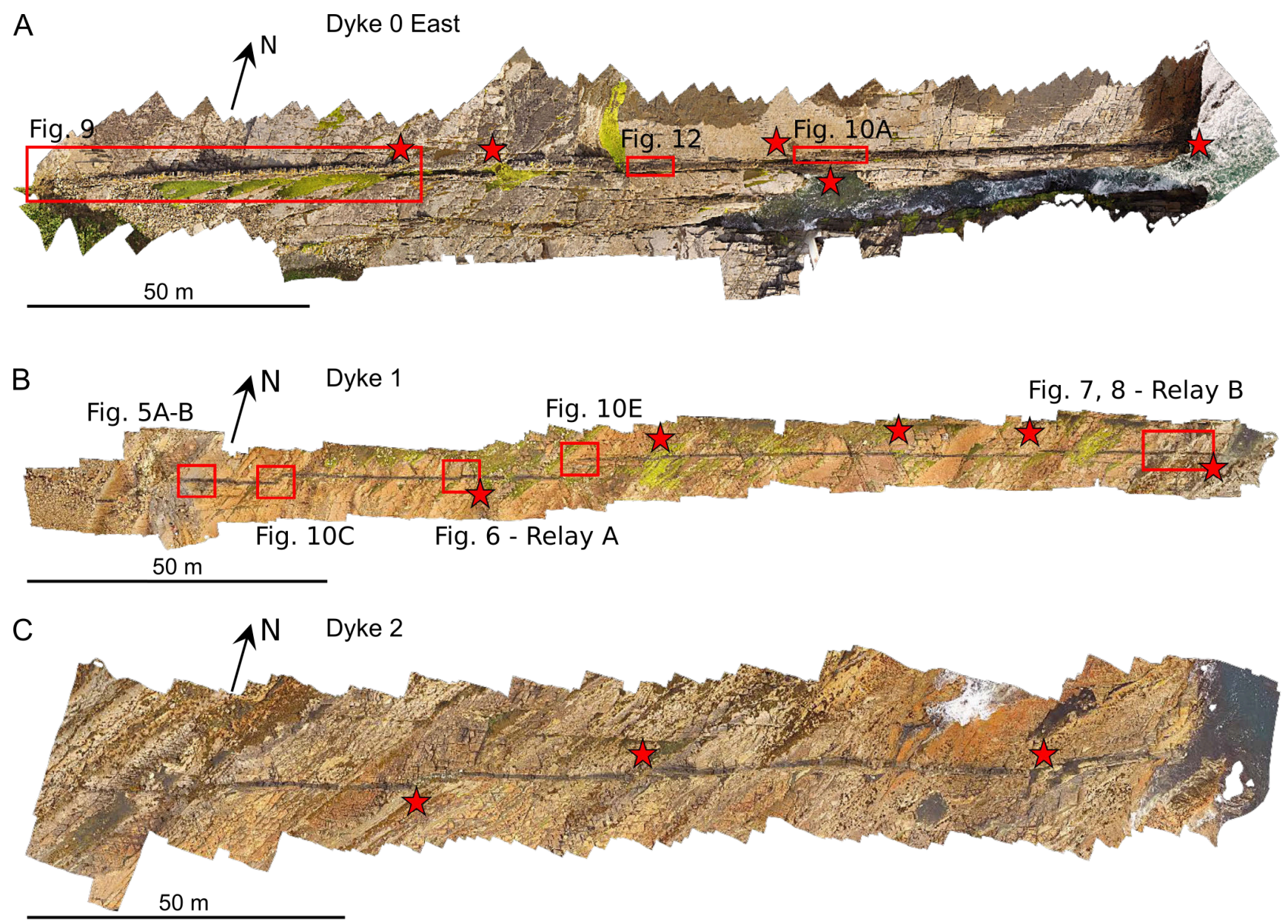

Figure 3: Orthorectified photo mosaics of the three dykes studied in detail. Dyke 0 East has a total exposed length of 225 metres, Dyke 1 has a length of 205 metres and Dyke 2 has a length of 186 metres. Note the segmentation of all three dykes, with the majority of segments left stepping, although right-steps do occur. Traces of bedding planes in the host rocks can be seen striking NE-SW. Red boxes mark the locations of the relay zones selected for detailed analysis in this paper. Red stars mark other locations where evidence for segment floors and/or roofs can be seen, although not documented in detail in this paper. High-resolution orthomosaics can be found at https://doi.org/10.6084/m9.figshare.6849827.v2.

$\left(10-20^{\circ}\right)$ to the NW (stereogram inset in Figure 6B). The floor to S1 appears planar and concordant to bedding, whereas the roof of S2 is concordant but gently domed, like the top of a loaf of bread. A further detail confirms this contact as the roof of segment S2: a small (approximately $15 \mathrm{~cm} \times 20 \mathrm{~cm})$, thin $(2-3 \mathrm{~cm})$ patch of baked mudstone and siltstone is preserved as a carapace on top of the dyke segment (Figure 6G-H). Segments S1 and $\mathrm{S} 2$ are connected by a thin $(10-20 \mathrm{~cm})$ sill-like body (Figure 6E-F).

\subsubsection{Relay B - Dyke 1}

This relay zone is actually three relays in close proximity (approx. $7 \mathrm{~m}$ along strike), linking four segments S1-S4. Note that at this ENE end of Dyke 1 (see Figure $3 \mathrm{~B}$ for location) the segments are approximately 30 $\mathrm{cm}$ wide (Figure 7A-B). From the perfect 3D exposure, the floor of segment $\mathrm{S} 1$ is clearly defined by the shallow dipping contact with bedding lying directly beneath (Figure 7C-D). This floor contact is planar and concordant, and dips at a shallow angle to the WNW (strike and dip of $026 / 34 \mathrm{~W}$ ).

For the next segment S2, the roof is also clearly visible and defined by the presence of bedding in the overlying stratigraphy (Figure 7C-F). The two segments S1 and S2 overlap by a few tens of centimetres and appear to be coalesced. The central segment in this relay zone (S3) is exposed in a steep segment margin-parallel joint surface, and clearly shows the segment floor dipping to the West, with host rock bedding truncated beneath (Figure 8A-B). Viewed along strike from the ENE, the segment floor is confirmed, with bedding passing continuously beneath the exposed width of the segment. The fourth segment in this system (S4) is joined to S3 by a narrow (few $\mathrm{cm}$ across) pipe-like body, flanked by host rocks with rotated (steepened) bedding (Figure $8 \mathrm{~A}-\mathrm{B}$ ). The roof to segment $\mathrm{S} 4$ is also clearly visible 

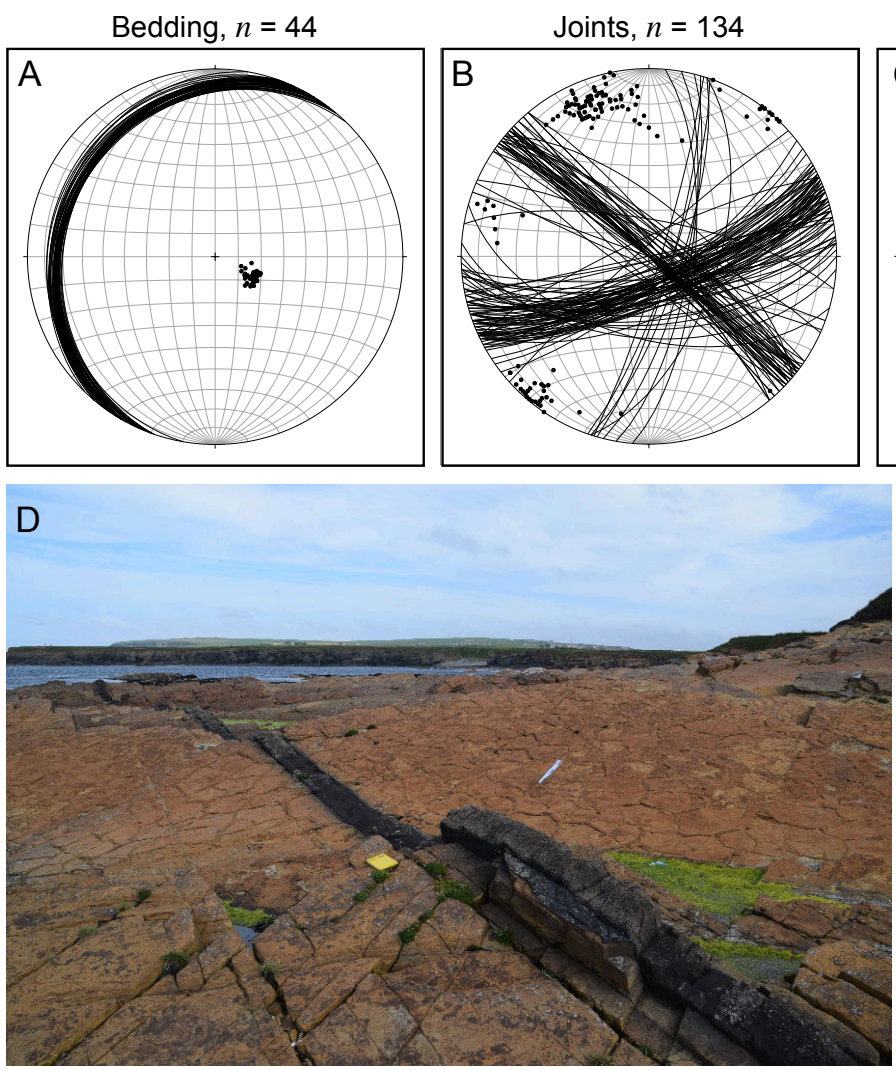

Dyke margins, $n=22$
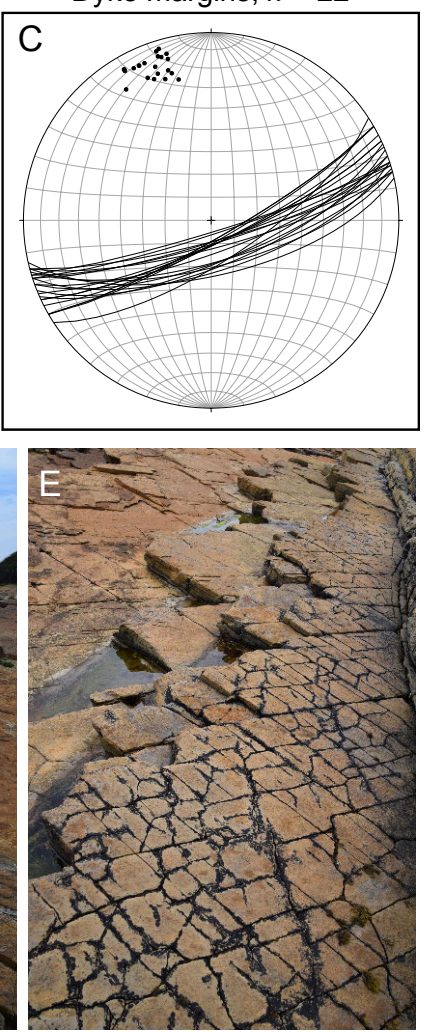

Figure 4: Orientation data from Birsay. Stereograms plotted as equal area, lower hemisphere projections, with great circles and poles. [A] The orientation of bedding is very uniform over the whole mapped area, with an average strike of approximately 030 and dipping approximately $20^{\circ}$ to the WNW. [B] Three prominent sets of joints are developed throughout the area, with two main sets oriented ENE/WSW and NW/SE, and a less welldeveloped set trending NNE. [C] Dyke margins (away from the segment tips) are also very uniform and follow the trend of one of the joint sets ENE/WSW, dipping steeply $\left(70-80^{\circ}\right)$ to the South.

with undisturbed and unfractured host rock bedding passing across the top. The roof to S4 dips at shallow angle $\left(\sim 10^{\circ}\right)$ to the WSW, and is gently domed in appearance (Figure $8 \mathrm{C}-\mathrm{D})$.

\subsubsection{Dyke 0 East}

Dyke 0 East provides two other features of interest to this study. This dyke stands proud of the host rock in a single segment approximately 50-60 metres long at the western end of the outcrop (Figure 9A-B). Viewed from the South, numerous shallow West dipping joint surfaces can be traced within the southern margin of the dyke segment. In detail, these intra-dyke joints are often concave upwards (Figure 9C-E). At the eastern exposed end of this segment, the dyke has a quasielliptical cross-section (Figure 9F-G) and is seen to overly bedded host rock. The floor contact can be traced for about 3 metres across the 'nose' of this segment tip and down along the segment flank. In addition, further exposed examples of floor and roof contacts are visible in the segment relays to the East (marked on Figure 3A).

\subsubsection{Steps}

There are many steps (or 'jogs') exposed along the three main dykes at Birsay, and they display a common pattern. The host rock in the area immediately along strike of lateral projection of the segments on either side of the step is intensely brecciated. The breccia clasts range in size from a few $\mathrm{mm}$ to a few $\mathrm{cm}$, are invariably angular and rotated. The clasts appear to be derived from the immediate host rock layer for the given level of exposure. In many cases, a locally intense zone of dyke margin parallel joints extends beyond the dyke terminations into the host rock. The baked margins widen around the step and then return to their normal width alongside the dyke segments extending away from the step.

\subsubsection{Joints}

Three joint sets are developed in the area, trending ENE, NNE and NW. The NNE set is the least well developed. The ENE set is parallel to the lateral margins of most dyke segments (Figure 4B-C). Near the segment relays, joint traces are observed to deflect around the segment tips, and in some cases are truncated by the 

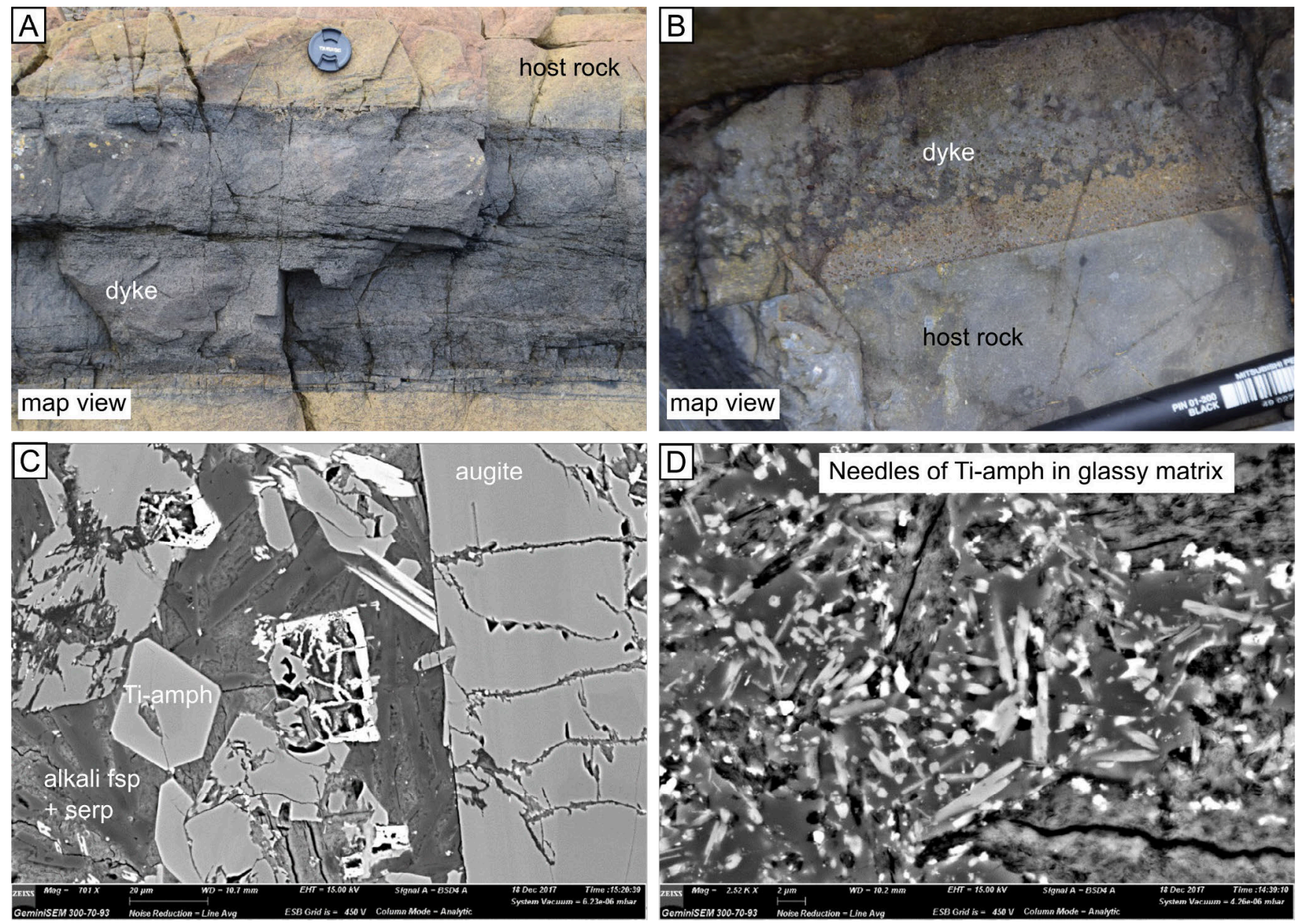

Figure 5: Details of the textures and mineralogies of the dykes at Birsay. [A] Photograph (map view, N at the top) showing a typical profile across Dyke 1, with chilled margins and a central core zone that often appears vesicular in the field (lens cap is $6.5 \mathrm{~cm}$ across). Note the discolouration of the host rock in the baked margin. [B] Photograph (map view, $\mathrm{N}$ at the top) showing details of a complex, probably composite, chilled margin within Dyke 1 (pen is $1 \mathrm{~cm}$ across). [C] SEM-BSE image of a thin section from the core of Dyke 1. The groundmass is made up of alkali feldspar and serpentine after olivine (occasional relics preserved). The phenocryst cargo includes Tirich amphibole (probably kaersutite) and zoned augite. Other phases include Mn-rich calcite, dolomite, quartz, Ni-rich pyrite and Cr-spinel. [D] SEM-BSE image of a thin section a chilled margin of Dyke 1 showing needles of Ti-rich amphibole in a glassy matrix.

dyke tip contact (Figure 10A-B). The frequency of ENE trending joints increases near the dyke segment tips and alongside their lateral margins. A scanline across Dyke 1 shows the increase in estimated fracture intensity (number of joints per metre) near the dyke margins. The host rocks have a background fracture intensity of between $10-30 \mathrm{~m}^{-1}$, but this rapidly increases within about $0.5 \mathrm{~m}$ of the contact to $>100 \mathrm{~m}^{-1}$. In the segment relays, joints are common in front of the segment tips, but less common in the host rocks immediately adjacent to the floor and roof contacts (Figures 6E, 7E, 8C). A handful of the NW trending joints are filled with calcite and these veins are observed to cut across the dyke segments.

\subsubsection{Vesicles}

As noted above, many dyke segments at Birsay contain vesicles, either in the central core or in paired parallel trains symmetrically disposed either side of the median line. Vesicles range in size from $<1 \mathrm{~mm}$ to $>5$ $\mathrm{mm}$ (longest dimension). Several of the paired parallel trains display a systematic asymmetry, or imbrication, of vesicle long axes viewed in the horizontal plane (Figure 12). For the example illustrated from Dyke 0 East, the northern vesicle train has long axes preferentially oriented ESE, a clockwise rotation of about $20^{\circ}$ with respect to the local segment margin. The southern vesicle train has long axes preferentially oriented ENE, a counter-clockwise rotation of approximately $10^{\circ}$ angle with the local segment margin. Vesicle cross-sections observed in sub-vertical joint surfaces are elongated, 

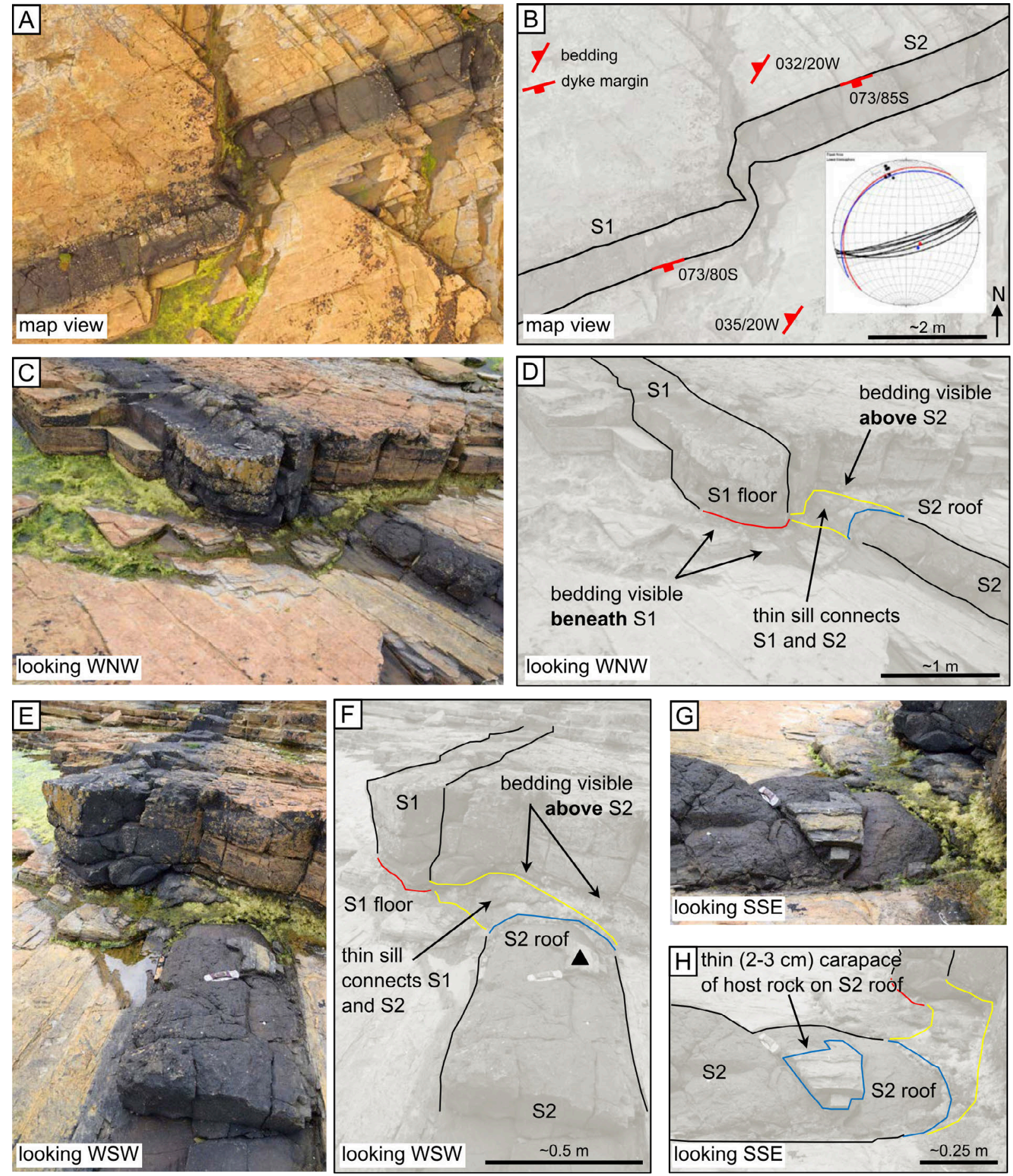

Figure 6: Field observations from Relay A on Dyke 1. [A]-[B] Photograph and interpretation in map view of the two segments S1 and S2. The apparent lateral offset is approximately the width of the dyke, about $45 \mathrm{~cm}$ at this locality. The inset stereogram in [B] shows the orientations of the dyke margins (black) and the interpreted floor and roof tip-lines (red and blue, respectively). [C]-[D] Photograph and interpretation of the geometry of this relay zone in oblique view looking WNW. Bedding in the host rock can clearly be seen beneath the easternmost outcrop of S1, and above the westernmost outcrop of S2. These contacts are interpreted as the local floor (red) and roof (blue) of these segments. The measured orientations of these contacts are shown in the stereogram in b). A thin (few cm across) sill-like body is seen to connect S1 to S2. [E]-[F] Photograph and interpretation of Relay A from a different viewpoint looking WSW to clarify the floor and roof geometries and the connecting sill. Note the gently domed appearance of the roof of S2, like a loaf of bread (near the penknife). [G]-[H] Photograph and interpretation of the roof of S2 (looking SSE) with a thin baked-on remnant of the host rock clearly visible on top of the S2 dyke segment. 

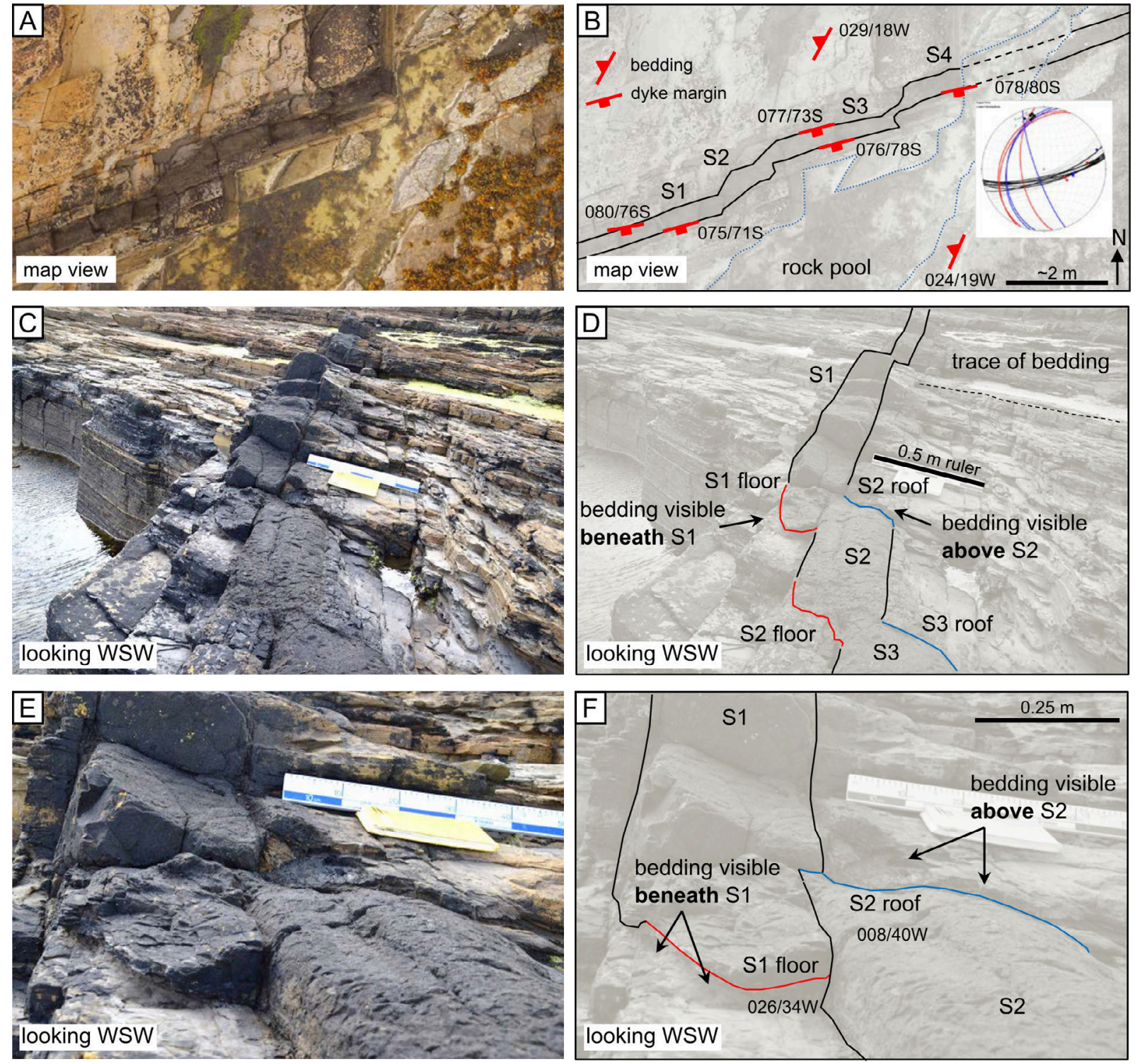

Figure 7: Field observations from Relay B on Dyke 1. [A]-[B] Photograph and interpretation in map view of four segments S1-S4. The inset stereogram in [B] shows the orientations of the dyke margins (black) and the interpreted floor and roof tip-lines (red and blue, respectively). [C]-[D] Photograph and interpretation of the relationship between S1 and S2, looking WSW. Bedding in the host rock is seen beneath S1 and above S2, these contacts are taken as a floor and a roof respectively. Bedding is again visible beneath the easternmost end of S2, and this contact is also interpreted as a segment floor. [E]-[F] Close-up photograph and interpretation of the S1 floor and S2 roof geometry shown in [C]-[D]. The measured orientations of these contacts are shown in the stereogram inset in [B]. Note again the gently domed appearance of the exposed top (roof) of S2, contrasted with the flat, bedding parallel base (floor) of S1.

with long axes sub-parallel to the local segment margin.

\section{INTERPRETATIONS}

\subsection{Dykes (away from relays and steps)}

The mineralogical and textural variations observed in thin section provide clues for the likely viscosity, temperature and density of the magma that solidified in these dykes. The abundance of amphibole and the deuteric alteration of olivine to serpentine suggest that the melt was rich in $\mathrm{H}_{2} \mathrm{O}$. The presence of primary Mn-rich calcite and dolomite suggest the presence of significant quantities of $\mathrm{CO}_{2}$. In this preliminary analysis of the composition and physical properties, we infer that the magma was relatively low temperature $\left(<1000^{\circ} \mathrm{C}\right)$, low density $\left(<2600 \mathrm{~kg} \mathrm{~m}^{-3}\right)$ and low viscosity. Further work is underway to quantify the modal proportions of the relevant phases and place tighter bounds on the crystallisation history and evolution of physical properties. 

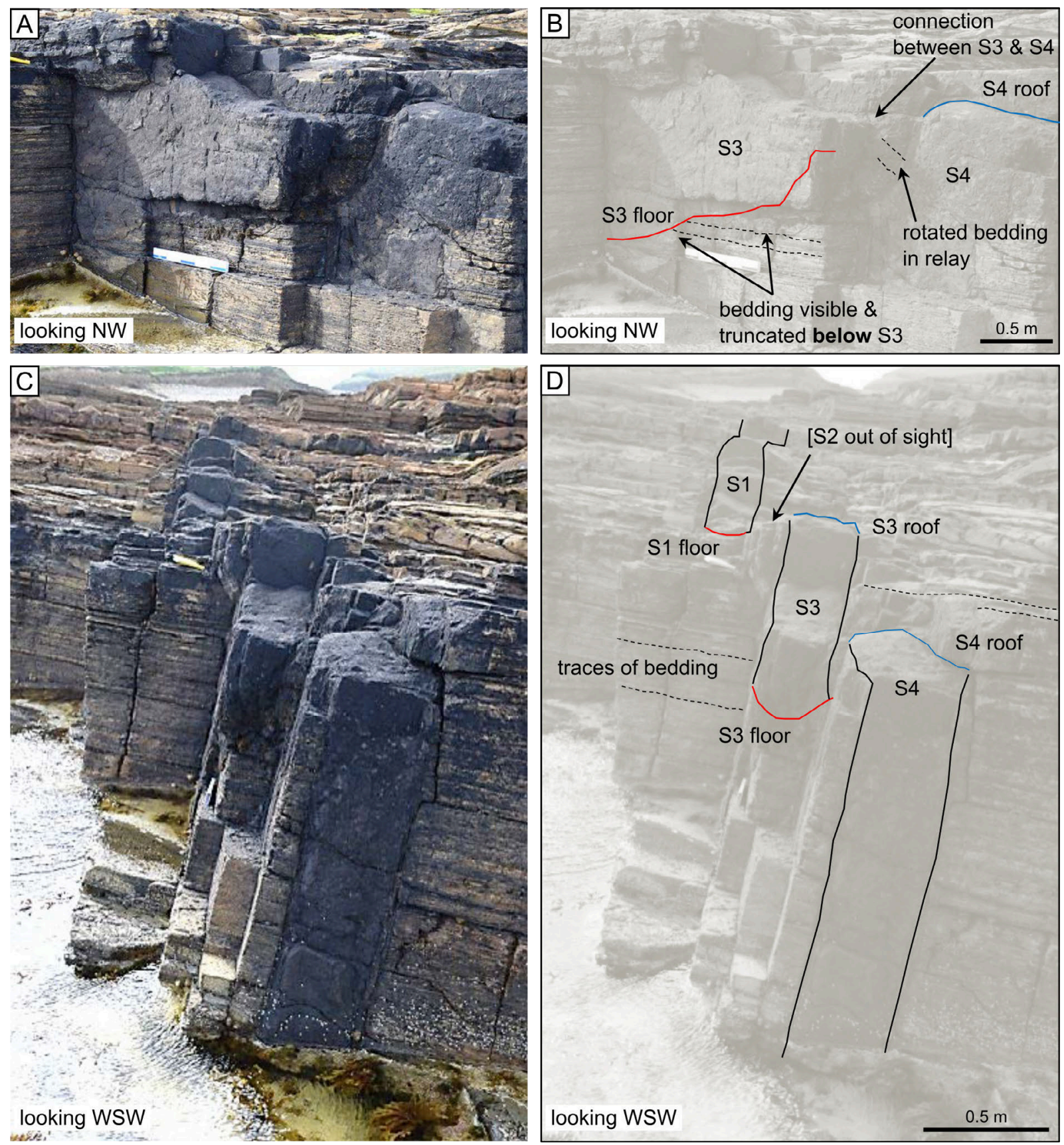

Figure 8: Further field observations from Relay B on Dyke 1. [A]-[B] Photograph and interpretation of the relationships between S3 and S4 at the eastern end of the relay. Looking NW onto a nearly vertical section along the southern margin of S3. The floor to S3 can be seen, with bedding in the host rock truncated against the dyke contact. The connection between S3 and S4 is complex, with rotated steepened bedding. [C]-[D] Photograph and interpretation of S3 and S4 looking WSW. The floor to S3 is clearly visible with host rock bedding beneath. The roof to S4 is also visible with bedding in the host rock continuous above. In the background, the floor to S1 is also visible. 

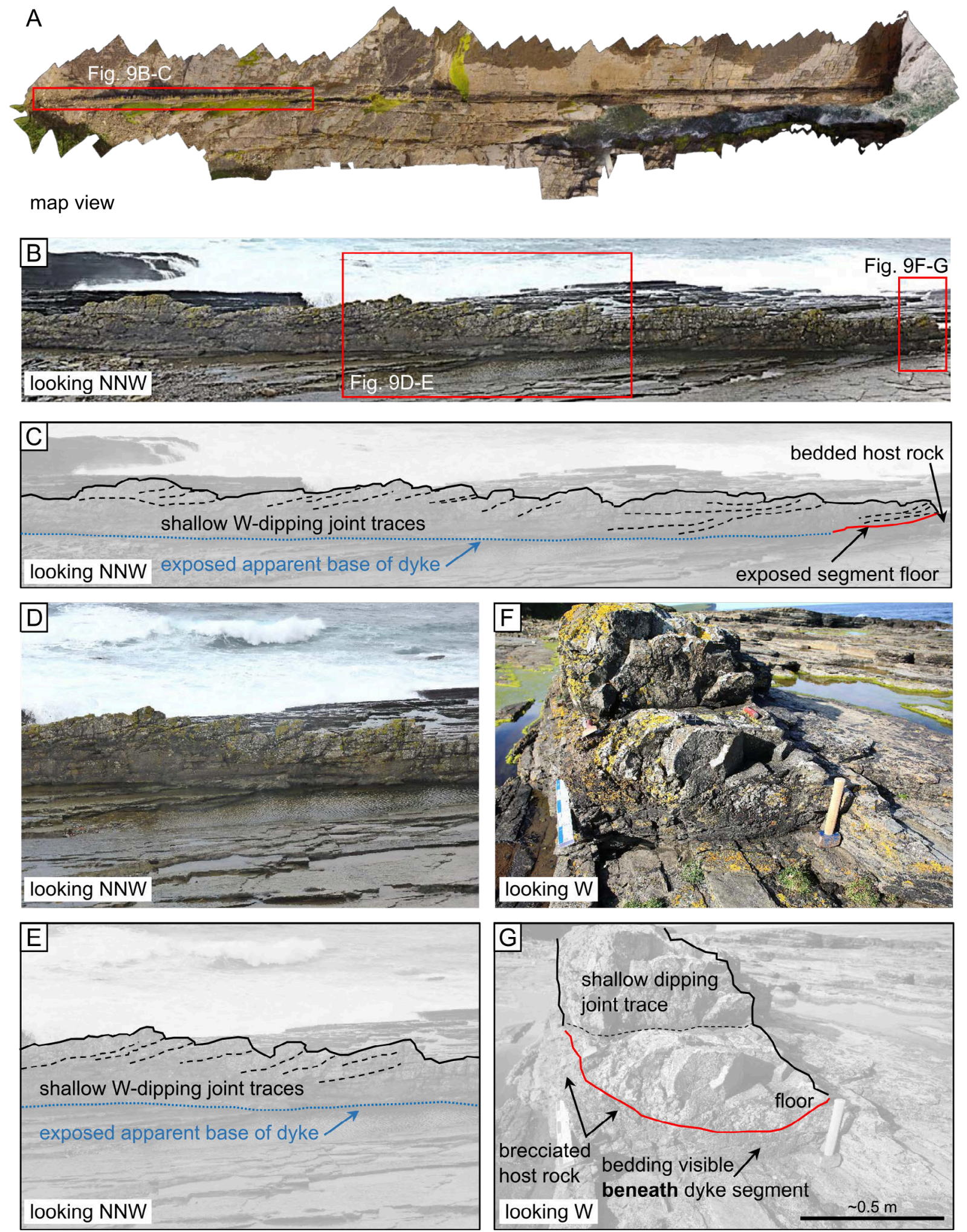

Figure 9: Caption on next page. 
Figure 9: Field observations from Dyke 0 East. [A] Orthorectified photomosaic of Dyke 0 East showing the location of the following images and analysis. [B]-[C] Stitched photomosaic and interpretation looking NNW of the western end of Dyke 0 East. The dyke forms a low (1-2 $\mathrm{m}$ high) wall running along the wave cut platform, and is cut by prominent shallow W-dipping joints, many with a concave-up geometry. Bedded host rock can be seen beneath the dyke at the eastern end of this outcrop, interpreted as the segment floor. [D]-[E] Close-up photograph and interpretation of the shallow W-dipping joints in this segment of Dyke 0 East. [F]-[G] Photograph and interpretation of the exposed tip at the eastern end of this segment, looking West. Traces of the shallow Wdipping joints can be seen within the dyke. Bedding is visible in the host rock beneath the exposed dyke tip, with the contact interpreted as the local segment floor (red line). The host rock is also brecciated in places around this tip.

\subsection{Relays}

The field evidence from the dyke relays at Birsay shows neighbouring segments with either a clear roof or floor, all dipping at shallow angles (about $20^{\circ}$ ) towards the West. Using these observed dip angles and the measured (apparent) length of the en echelon segments at the present level of erosion, we can estimate the segment height as apparent length $\times \sin ($ dip of roof or floor). With a maximum segment apparent length of 50 metres, this simple formula yields an upper bound estimate of segment height $=50 \times \sin (20)=17$ metres. Therefore, these segments are much longer than they are high. The juxtaposition of a segment floor and a segment roof at each relay (Figure 13A, C) implies that either a) the dyke segments are stepping down topographically to the East, or b) that the segments themselves are tilted with their long axes (parallel to segment strike) plunging at shallow angles to the West. The wave cut platform at Birsay is essentially at, or very close to, sea level: there is no significant topographic variation. Therefore, it seems most likely that the segments are tilted at a shallow angle to the West and step down stratigraphically through the NW dipping host rock sequence, while maintaining a broadly constant level within the crust. The observed floor and roof contacts all dip at low angles to the WSW, W or WNW: there are no observations of steeply plunging segment tip-lines as would be expected in the model of Delaney and Pollard [1981] for a vertically propagating dyke with a segmented upper edge. Based on our field observations at Birsay, we consider the individual dyke segments to be broadly ellipsoidal in outline, with their lengths $\gg$ heights $\gg$ widths, and their long axes tilted towards the West (Figure 13). Connectivity between segments is maintained through thin sills and pipes observed at the relays, which are therefore 'hard-linked' in the parlance of fault relay zones [e.g. Walsh et al. 1999]. While individual segments vary in size and aspect ratio, the overall pattern is consistent with the segments maintaining a constant structural level within the dipping stratigraphy. The Birsay dykes appear to be segmented from top to bottom i.e. the whole vertical extent of the dyke is segmented, and these segments do not merge downwards into a continuous sheet. The present day orientation of the dyke segments with respect to the bedding is consistent with the host rocks being tilted (i.e. folded) prior to dyke emplacement: this interpretation is in turn consistent with evidence for sedimentary basin inversion in the Carboniferous [Marshall et al. 1985; Parnell 1985].

\subsection{Joints}

The dyke segment margins are seen to be parallel to the ENE trending joints, with some of these joint traces deflected and truncated by dyke contacts at their tips. It is thus tempting to infer that the ENE trending joints pre-date dyke emplacement. However, the scan line data across Dyke 1 (Figure 11) and qualitative observations from the other dykes shows that fracture intensity increases alongside the dyke segment margins. This would suggest a genetic relationship between the dyke emplacement and the formation of at least some of the ENE joints. We speculate that the dykes were emplaced into pre-existing ENE trending joints, and the thermal impact of the dyke promoted margin-parallel hydrofractures in water-saturated sedimentary rocks [e.g. Townsend 2018]. Note also that the overall leftstepping geometry of the segments in all three dykes implies a component of right-lateral shear during emplacement.

We infer that the minimum horizontal stress was oriented approximately NW/SE during dyke emplacement, promoting oblique extension (transtension) of the pre-existing ENE joint set. It is noteworthy that joint frequency is not high in the host rocks immediately adjacent to the segment floor and roof contacts, a point also made by Gudmundsson [1983] for dykes in Iceland. This has implications for the mode of propagation of each segment within its own plane, and is discussed below in relation to mechanical models. We do not see any evidence of dyke perpendicular joints, which in other places have been related to hydrofracturing events from thermal pressurisation due to dyke emplacement [Townsend et al. 2015].

The westernmost segment of Dyke 0 East displays clear examples of intra-dyke joints, with numerous shallow West dipping fracture planes, many with a concave-up geometry. We interpret these as internal contacts separating batches of solidified magma em- 

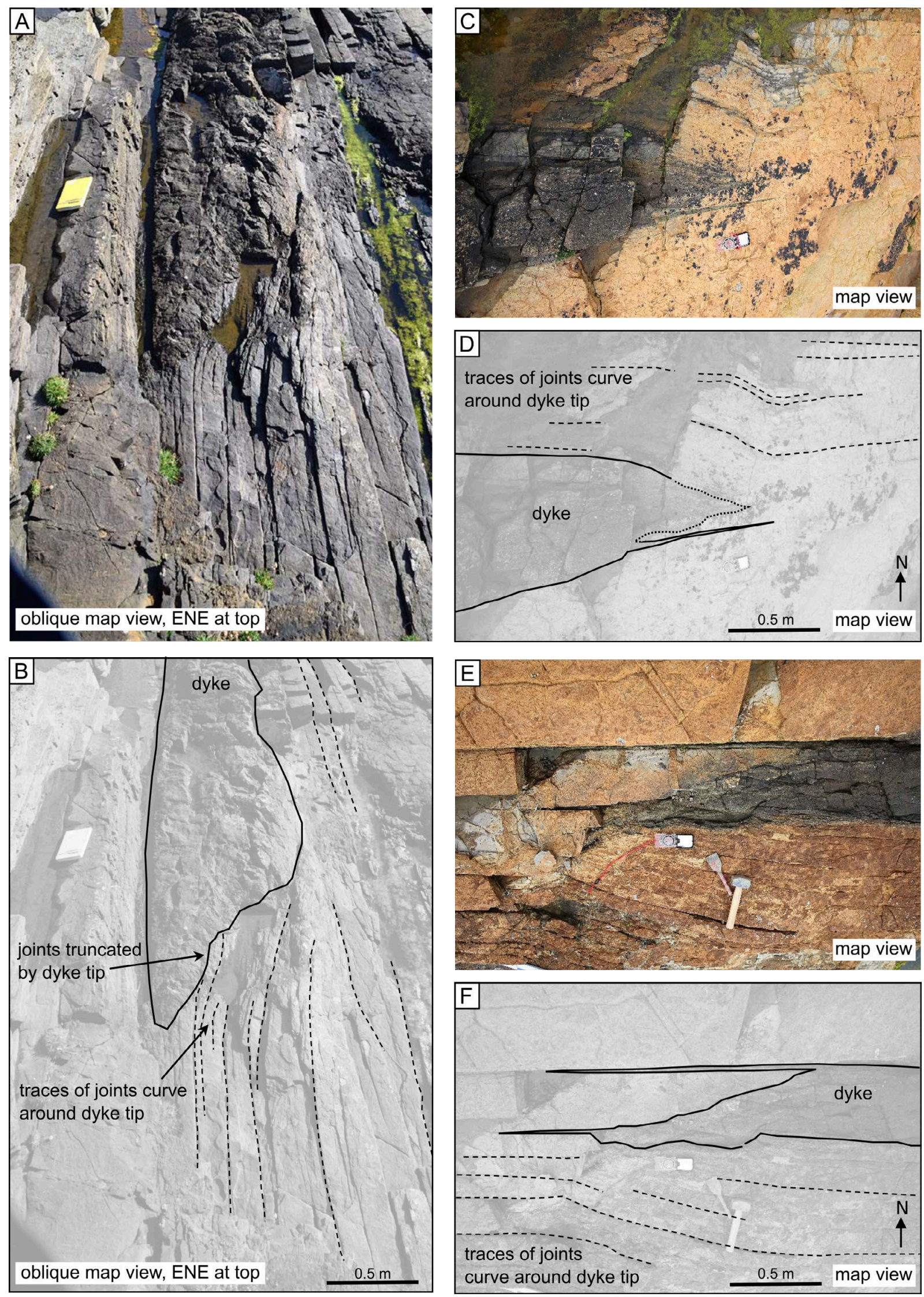

Figure 10: Caption on next page. 
Figure 10: Intense fractures at segment tips. [A]-[B] Photograph and interpretation of dyke/host joint relationships at a segment tip in Dyke 0 East. Oblique view, looking down and along to ENE. Note the truncations of some host rock joints by the dyke contact, and the deflections of host rock joint traces away from the generally uniform ENE/WSW trend. [C]-[F] Two further examples from segment tips in Dyke 1, showing the apparent deflection of host rock joint traces around the dyke tips.

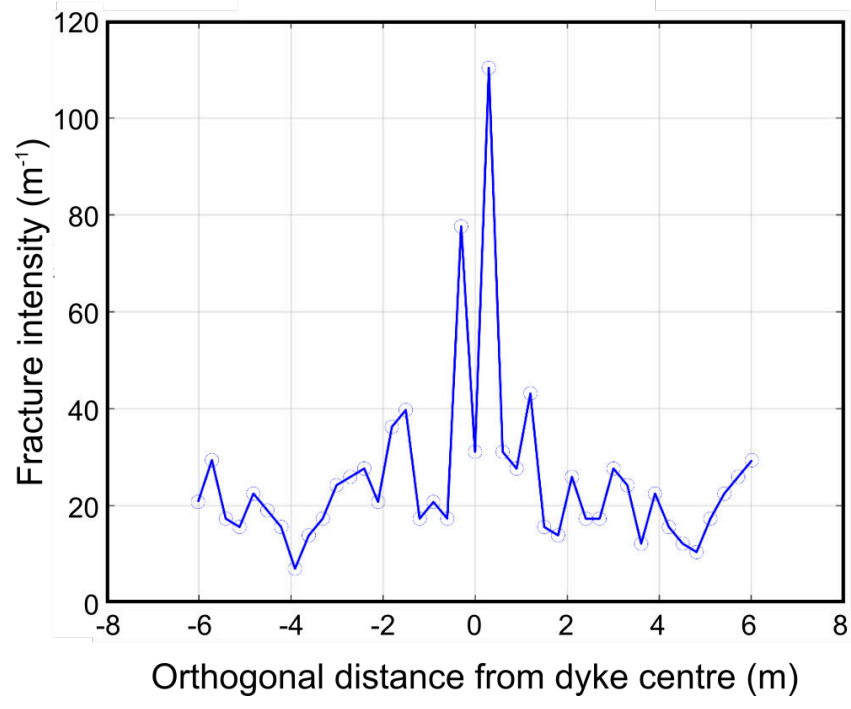

Figure 11: Example of estimated fracture intensities around a dyke segment. Estimated fracture intensity (number of fractures/metre) has been plotted against orthogonal distance from the centre of one segment of Dyke 1. At this locality, this segment of Dyke 1 is approximately $50 \mathrm{~cm}$ thick. Away from the dyke, estimated fracture intensity varies from about $10 \mathrm{~m}^{-1}$ to about $30 \mathrm{~m}^{-1}$. Within one dyke width (i.e. $0.5 \mathrm{~m}$ ), the estimated fracture intensity jumps to $>100 \mathrm{~m}^{-1}$.

placed upwards at a shallow angle from the WSW towards the ENE. Less well-developed examples occur throughout segments of Dyke 1 and Dyke 2.

\subsection{Vesicles}

The paired trains of inequant oriented vesicles shown in Figure 12 are interpreted as shear zones, marginal to a flowing central core of magma in this segment moving from the WSW to the ENE. The lack of any significant asymmetry of vesicle long axis orientations in the vertical plane implies this flow was dominantly horizontal at this locality. At other locations in Dykes 1 and 2, some apparent 'vesicles' could be weathered out phenocrysts. Nevertheless, their inequant form and systematic asymmetry over paired trains either side of the median line leads to the same conclusion: subhorizontal magma flow from WSW towards ENE.

\section{Discussion}

\subsection{Dyke segment and relay geometry}

Exposures of dyke relay zones at Birsay display shallow dipping floor and roof contacts of neighbouring dyke segments. None of the observed segment tip contacts are steep (i.e. dipping or plunging $>45^{\circ}$, see Figure 1 ). The observed geometry is therefore inconsistent with the classical model of Delaney and Pollard [1981], with a segmented 'fringe' above a continuous dyke at depth. Previous work on laterally emplaced, depth-restricted silicic dykes described a form of segmentation along the upper edge of a continuous dyke at depth [Poland et al. 2008, their Figure 8], but the segment tip-lines are shown as steepening into the continuous deeper sheet. This is also inconsistent with the observations from Birsay. The repeated juxtaposition of consecutive segment floor and roof contacts in the dyke relays at Birsay suggests that each dyke segment, and therefore the dyke as a whole, is depth-restricted; i.e. maintaining a more or less constant depth within the crust. While the dyke segments cut down stratigraphy to the ENE, the host rocks were already tilted at the time of intrusion in the late Permian and the exposed dyke segments are maintaining approximately the same depth within the upper crust. The model of Pollard et al. [1975] for fingered sheet intrusions could be applied to Birsay, with a rotation of up to 90 degrees; e.g. their figure $16 \mathrm{~B}$, rotated about their x-axis. We believe this is unlikely at Birsay for two reasons. Firstly, we don't see progressively more merged or coalesced segments in any particular direction parallel to strike (e.g. ENE or WSW) at Birsay (or elsewhere on Orkney) and secondly, this configuration cannot produce a dyke that is vertically restricted to a narrow depth range in the crust.

Connections between the segments have been observed at most of the dyke relays. The geometrical form of these connecting bodies varies from thin (few $\mathrm{cm}$ thick) sills to steeper tubular pipes. All segments in a given dyke must have been connected at some point, although some pathways might close as magma pressure wanes during drainback events (see below). The dyke relays at Birsay are generally 'hard-linked' in the parlance of fault relays: many segments are visibly joined by connecting bodies of dyke material. Many of these connecting bodies are small in relation to the neighbouring segment size. We speculate that the inferred low viscosity of this alkaline, volatile-rich $\left(\mathrm{H}_{2} \mathrm{O}\right.$ and $\mathrm{CO}_{2}$ ) magma may have been critical in facilitating sufficient flow through narrow apertures. 

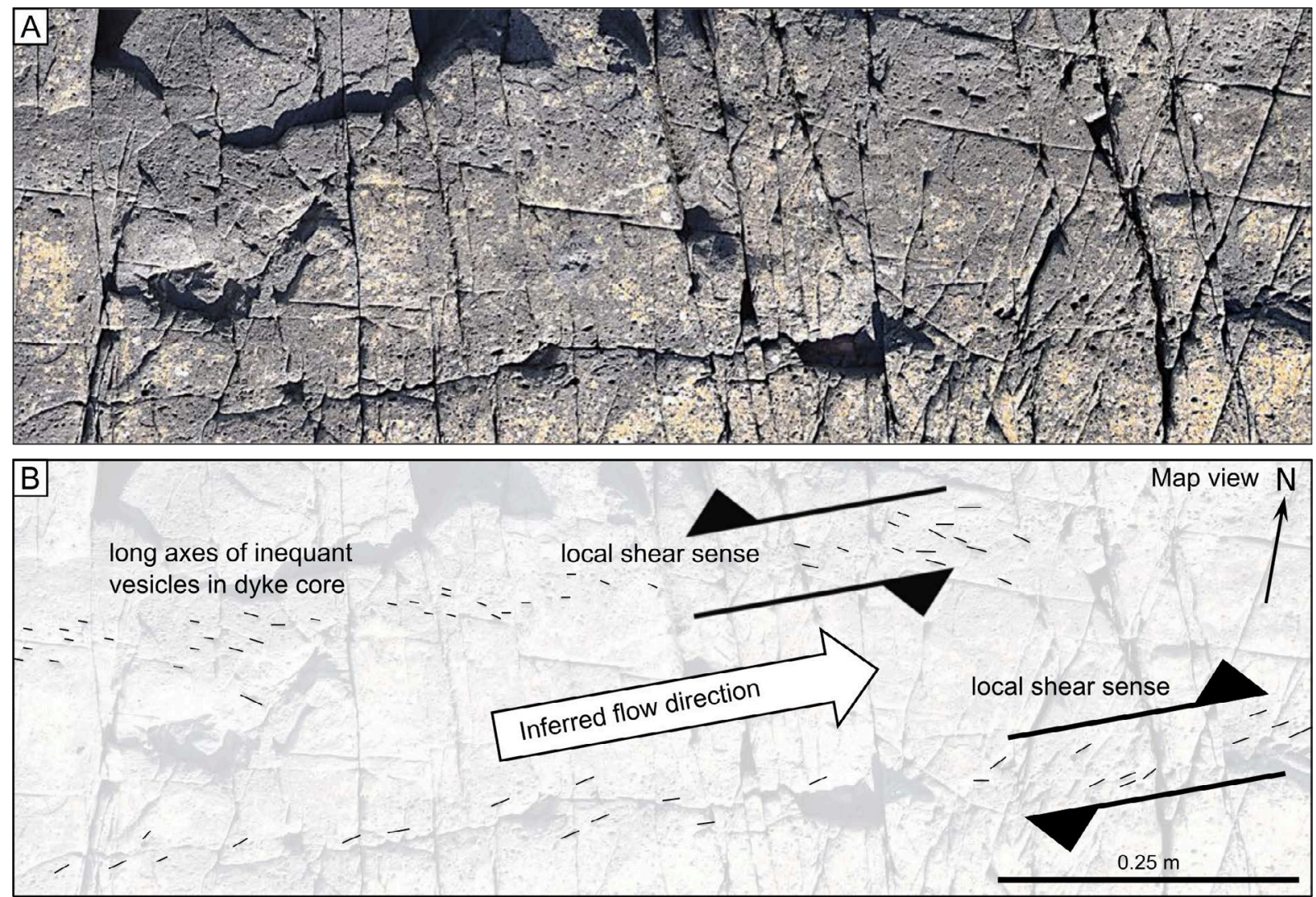

Figure 12: Preferred orientations of shaped vesicles in Dyke 0 East. [A]-[B] Photograph and interpretation of patterns of vesicles observed in the core of one segment of Dyke 0 East (see Figure 3 for location). Only about 1 metre of the dyke is shown, but this pattern extends for at least 10 metres on the ground. Two sub-parallel trains of vesicles can be found each about $20 \mathrm{~cm}$ in from the dyke margin. Many vesicles are elliptical in this horizontal (map view) cross-section, with their long axes oriented in opposite trends on either side of the dyke centre line. The northernmost vesicle train has long axes oriented approximately WNW/ESE whereas the southernmost train has long axes oriented approximately ENE/WSW. Assuming the vesicles were originally spherical with circular cross-sections in 2D, this pattern is consistent with a shear deformation due to eastward flow of the dyke core.

The outcrops at Birsay display a wide variety of segment tip geometries, with none of the relays showing identical morphologies (compare Figures 6, 7 and 10). Tip shapes include blunt, pointed or rounded, some with horn-like apophyses or multiple sheet-like fingers [Pollard et al. 1975; Nicholson and Pollard 1985]. We speculate that this may be due in part to the varied mechanical stratigraphy of the thinly bedded host rock sequence. Most beds are a few tens of centimetres thick and therefore, at the present level of erosion, every segment tip is in a slightly different lithology of different thickness. This lithological variation has consequences for the local fracture toughness that may control tip propagation [e.g. Hoek 1994]). Further work is in progress to quantify these mechanical variations in relation to the range in observed tip geometry.

\subsection{Magma source and emplacement direction}

A range of indicators suggest that the dykes propagated from the WSW towards the ENE, including:

- segment thicknesses within all three dykes decrease towards the ENE;

- asymmetry of long axes in paired trains of inequant and oriented vesicles imply that the central cores of dyke segments flowed sub-horizontally and from WSW to ENE;

- shallow West-dipping, concave up internal joints, interpreted as internal contacts, suggest magma emplacement from slightly deeper in the WSW upwards and along towards the ENE.

Dyke width is not necessarily simply related to proximity to source: width scales with overpressure and segment length, and thus the wider segments might be further from the source. However, overall we believe the balance of evidence favours a deeper source 

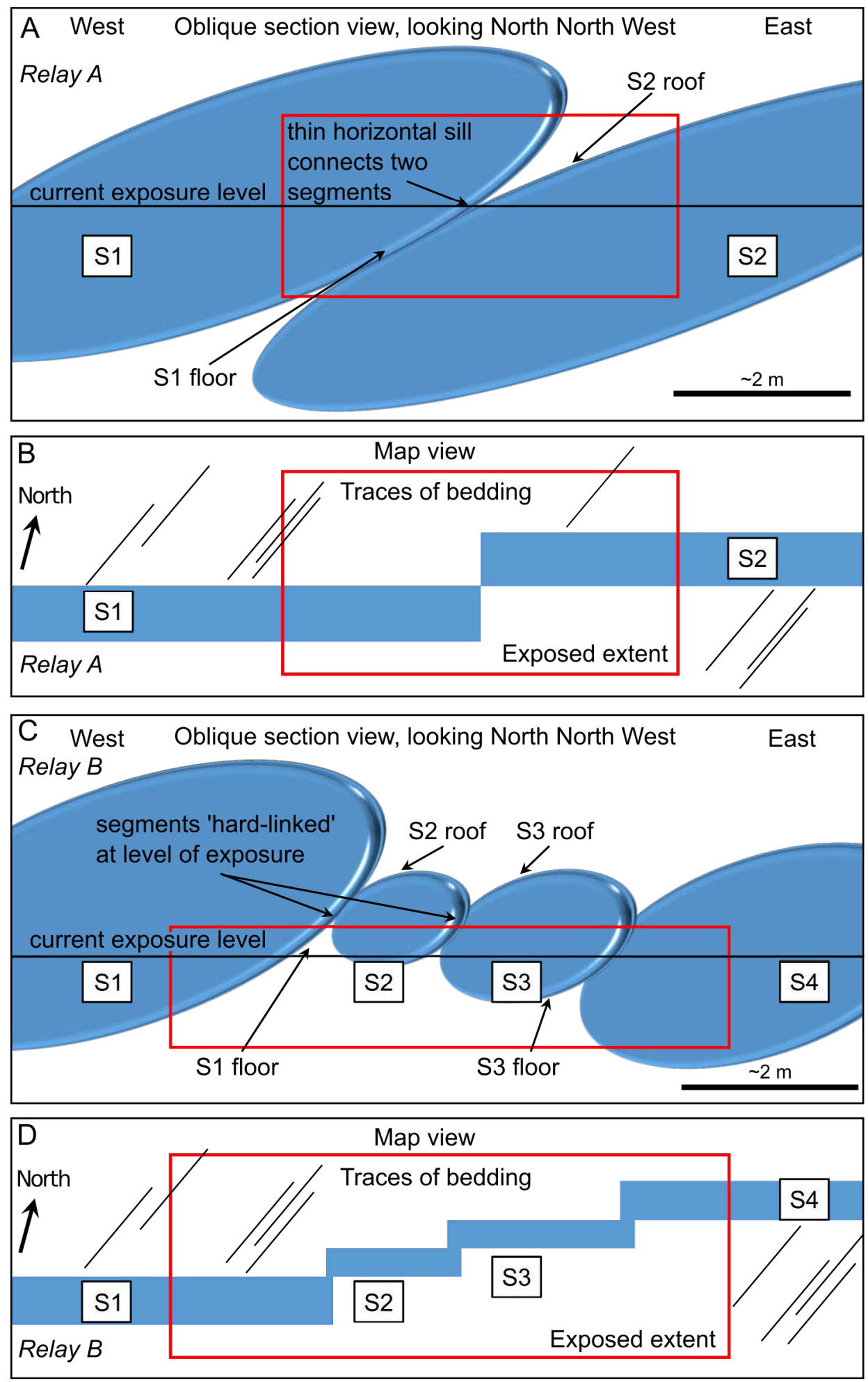

Figure 13: Summary models of field observations from the relays and their interpretations. $[\mathrm{A}]-[\mathrm{B}]$ Schematic idealised section and map view of Relay A, with the segments modelled as two thin ellipsoidal sheets, oriented with their longest axes inclined to the horizontal, and steeply dipping to the South. In the section view, S2 is further back (North) than S1. The red box denotes the region covered by Figure 6. The location of the thin connecting sill (not shown) is marked. The close juxtaposition of a shallow dipping floor and a roof contact is clearly shown, at the current level of exposure. [C]-[D] Schematic idealised section and map view of Relay B, with the segments modelled as four thin ellipsoidal sheets, oriented with their longest axes inclined to the horizontal, and steeply dipping to the South. In the section view, segments S2-S4 step back (to the North). The red box denotes the region covered by Figures 7 and 8 . The close juxtaposition of multiple shallow dipping floor and roof contacts is clearly shown, at the current level of exposure. 
of magma towards the WSW, i.e. offshore mainland Orkney and buried in the West Orkney Basin. Gravity surveys of the region are consistent with higher density, possibly magmatic, material lying immediately offshore to the WSW of mainland Orkney [Kimbell and Williamson 2016, their Figure 6].

\subsection{Comparison to modern volcanic systems}

Seismological and geodetic data from modern volcanic systems have been used to infer lateral emplacement of magma for tens of kilometres away from erupting volcanoes. The 2014 sequence at Bárðarbunga-Holuhraun on Iceland has been documented by Ágústsdóttir et al. [2016], and shows seismic activity extending $48 \mathrm{~km}$ away from the source and depth restricted to between 3 and $7 \mathrm{~km}$. The base to these events is sharper than the top, suggesting some kind of depth control on emplacement. Fissure eruptions occurred at intervals along the length of this activity. The seismic events are clearly clustered in space and time [Ágústsdóttir et al. 2016, their Figure 1], and these probably represent discrete segments of the larger dyke.

The most recent activity at Kīlauea on Hawaii (starting 30 April 2018) also produced spectacular fissure eruptions at the surface in the Lower East Rift Zone, following deflation at the Kilauea vent. The temporal sequence of these eruptions is generally down-rift, but with occasional jumps back towards the Kilauea vent [USGS Hawaiian Volcano Observatory 2018]. The surface fissures are arranged en echelon striking ENE, and are generally left-stepping. Compilations of seismological, geodetic and field data from the longer term, combined with mechanical analysis, have generated a detailed model for the sub-surface of Kilauea [Ryan 1988, his Plate 1]. The intrusions underlying the East Rift Zone are shown with a clear and sharp base. We speculate that the internal structure of this intrusion may resemble the segmented dykes at Birsay, albeit on a much larger scale.

Previous activity at Krafla (Iceland) in 1977 displayed many similarities to the patterns described above: lateral migration of seismic activity away from a deflating main vent, with the events restricted to a narrow depth range (3-6 km; Brandsdóttir and Einarsson [1979]). A potentially significant point to emerge from all of these studies, and made by Delaney and Pollard [1981], is that magma undergoes flow reversals, socalled 'drainback' events, during these periods of activity. For dykes preserved in the geological record this means that flow indicators from fabrics measured in dykes (vesicle or phenocryst orientations, or anisotropy of magnetic susceptibility) may be highly variable, and therefore unreliable in trying to discriminate lateral from vertical emplacement. Analysis of the geometrical form of the dyke segments and their relationships in well-exposed dyke relays, as in the current study, provides an alternative strategy.

\subsection{Physics of lateral dyke emplacement}

A mechanical model for the lateral emplacement of dykes at constant depth in the crust has recently been described by Townsend et al. [2017] and Pollard and Townsend [2018], building on previous work by Rubin and Pollard [1987] and Rubin [1995]. The emplacement at a specific depth depends on a subtle interplay between the magma driving pressure (magma pressure minus the dyke-normal remote stress), the fracture toughness of the host rocks $\left(K_{I c}\right)$, the stress intensity factors at the dyke (segment) top, bottom and lateral tips, and the density structure of the crust. Considering the Birsay dyke segments as thin blade-like ellipsoids in $3 \mathrm{D}$, with low heights $(<20$ metres) in relation to their lengths (50 metres), vertical gradients in either magma pressure or in dyke-normal horizontal stress are unlikely to be significant. Similarly, variations in $K_{I c}$ are not likely to be significant in these thinly-bedded and well jointed sedimentary rocks.

Field evidence suggests that the dyke segments were emplaced into pre-existing joints, albeit with some local enhancement of joint frequencies at the segment lateral margins. The current geometry of the dyke segments is therefore a function of this original joint pattern. The mechanics of joint formation is likely different from magma-filled crack propagation, especially for these 'dry' (unmineralised) joints. We infer that the driving pressure from magma emplacement did not achieve stress intensity factors at the pre-existing joint tip-lines sufficient to propagate them further, consistent with the evidence that the host rocks immediately adjacent to the floor and roof contacts of the segments are not noticeably fractured. Joints of the ENE trending were passively inflated, and as these were slightly misoriented with respect to a minimum horizontal stress $\left(\sigma_{h}\right)$ aligned NW/SE, magmatic connections along the NNE trending joint set and/or bedding planes were exploited to 'correct' the overall dyke path towards the NE (i.e. perpendicular to $\sigma_{h}$ ). On a larger crustal scale, the Devonian (lacustrine) host rocks may constitute a relatively low density layer bounded below by higher density 'Caledonised' basement [Strachan 2003], and above by higher density sand-rich (fluvial) Carboniferous rocks [Marshall et al. 1985; Parnell 1985]. This may explain the relative abundance of Permian dykes in the Devonian of Orkney and Caithness. Further work is underway to quantify the likely viscosity, density and temperature of the volatile-rich magma in these dykes to provide better constraints on the mechanics of their emplacement.

\subsection{Implications for other dyke systems}

The observed geometry of the segmented dykes at Birsay has implications for the analysis and interpretation of dykes in other areas. The North Atlantic Igneous Province (NAIP) contains many basaltic dykes spread 

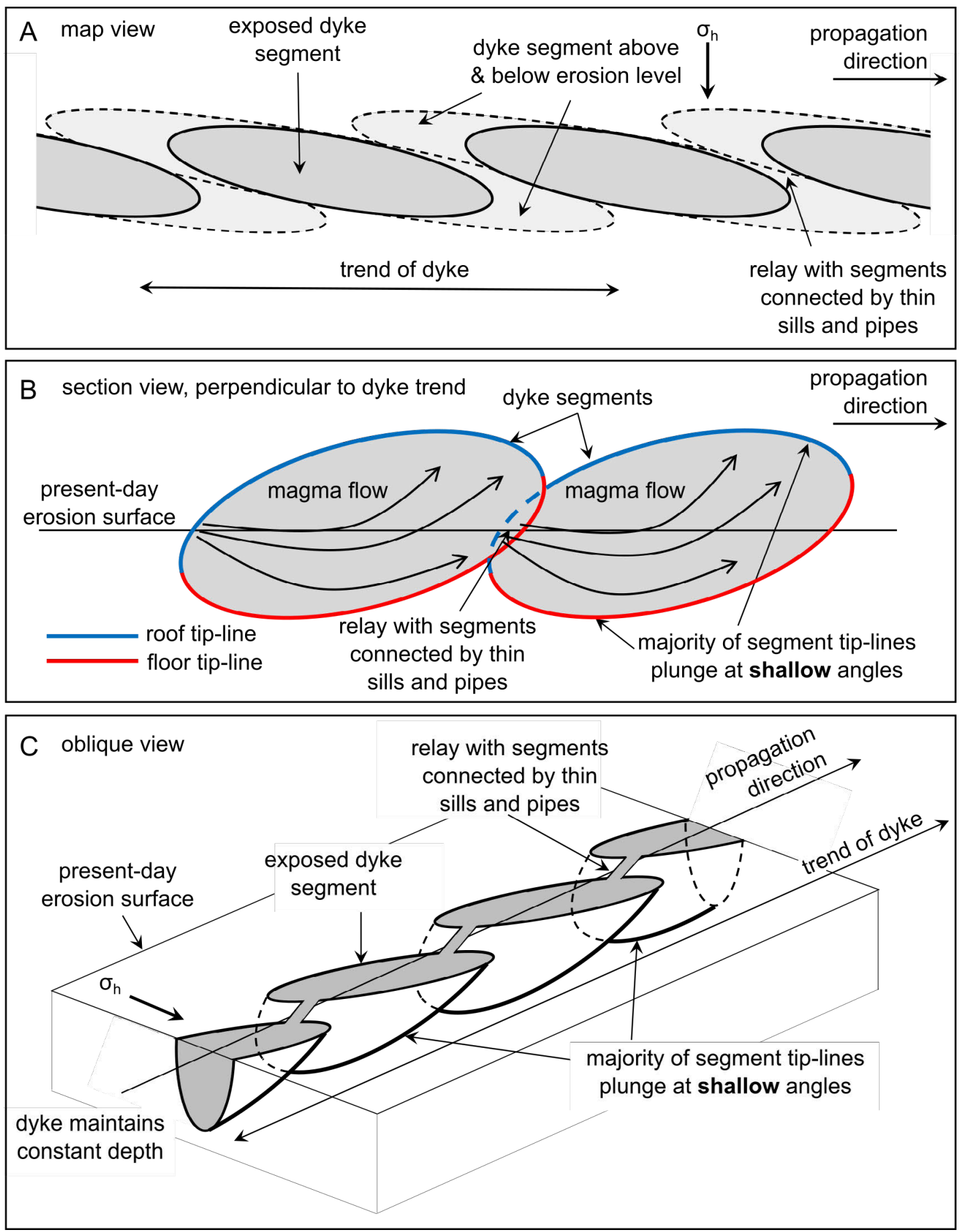

Figure 14: Summary diagrams of a new geometrical model for lateral dyke emplacement based on field evidence at Birsay. [A] Schematic map view showing discrete en echelon dyke segments (grey) and their inferred extent above and below the current exposure level (light grey). Connecting sills, dykes and pipes in the relay zones are omitted for clarity, as, based on the evidence from Birsay, they are much smaller than the segments they connect. $\sigma_{h}$ denotes the inferred orientation of the minimum horizontal stress at dyke emplacement, perpendicular to the overall dyke trend. [B] Oblique section view showing the dyke segment floor and roof tip-lines (red and blue, respectively), and their close juxtaposition in the exposed relay zone. Note that the majority of the floor and roof tip-lines plunge at shallow angles. The segment long axes are inclined to the horizontal to produce relay zones with the floor of one segment juxtaposed with the roof of the next segment. Schematic flow lines show the inferred direction of magma emplacement. [C] Schematic oblique 3D view of multiple en echelon segments and their relays. Note that the dyke is segmented over the whole vertical extent, and maintains a constant depth. $\sigma_{h}$ denotes the inferred orientation of the minimum horizontal stress at dyke emplacement, perpendicular to the overall dyke trend. 
over much of northern and western Scotland, many of which are clearly related to discrete central complexes [Emeleus and Bell 2005]. Work is under way to analyse selected dyke segment relay zones to map out the geometry of the tip-lines. Dyke suites are critical markers for geologists working in high-grade gneiss terrains, such as the Lewisian Complex of Scotland. The Scourie dyke suite has been used to separate earlier (Badcallian, Inverian) from later (Laxfordian) structural and metamorphic events in the mid-crust [see Wheeler et al. 2010, for a recent review]. Considering these as originally segmented, depth-restricted and laterally emplaced might change some of the structural and tectonic interpretations in these rocks. Igneous systems like the NAIP contain networks of dykes and sills now preserved in offshore sedimentary basins [e.g. Wall et al. 2010; Schofield et al. 2012; Magee et al. 2014]. Imaging of sub-vertical dykes in seismic reflection data has long been a problem, but insights from our work at Birsay combined with the mechanical models for lateral dyke emplacement [Townsend et al. 2017; Pollard and Townsend 2018] suggest that seismic processing to image these intrusions might best be concentrated in the lower density intervals within the stratigraphy, or at the depth of significant density contrasts.

\section{Summary}

We have presented detailed field evidence for the lateral emplacement of segmented camptonite dykes at Birsay (Orkney, UK). We show that:

- the exposed segments are juxtaposed in relay zones, with shallow dipping floor and roof contacts;

- there is no evidence for these segments merging downwards into a continuous sheet at depth;

- the dykes are segmented over their whole vertical extent, and can be visualised as oblate ellipsoidal sheets with length $\gg$ height $\gg$ width;

- the segments must be tilted in relation to the present day surface, with their strike-parallel long axes dipping at shallow angles (10-20 degrees) towards the West;

- the dykes overall therefore maintain a roughly constant structural level within the dipping stratigraphy.

At the relays between adjacent dyke segments, the orientations and geometrical relationships of the exposed segment roof and floor contacts strongly suggest that, at least in this region, the dykes were not propagating vertically from below. Instead, the dominant direction of dyke propagation and magma flow was sub-horizontal, probably from WSW to ESE. Thus, the presence of en echelon dyke segments at the surface does not necessarily imply downward connection to a continuous vertically propagating dyke at depth [Delaney and Pollard 1981]. The observed and measured orientations of the segment tip lines-the floors and roofs of the individual segments-are critical in this regard.

Our observations provide novel prima facie geometrical evidence for lateral dyke emplacement that complements existing seismological and geodetic data from modern volcanic systems and fabric data (vesicle, phenocryst, or palaeomagnetic) from outcrops of older dykes. The lateral emplacement of segmented, depth-restricted dykes has consequences for geological interpretations of seismic reflection data in sedimentary basins and for those trying to unravel complex polyphase structural and metamorphic histories in basement gneiss regions. Careful field observations of segmented dykes in other regions will provide important insights for the next generation of 3D physical models of dyke emplacement.

\section{Acknowledgements}

We thank the USGS Hawaiian Volcano Observatory for help with accessing Kîlauea seismicity data, Steven Andrews at Camborne School of Mines for help with the sedimentology and John Howell (Aberdeen) for the lend of a drone. John Still is thanked for help with the SEM at Aberdeen. DH and NF thank Katie and Dave Farrell for 'baby-sitting' services while the fieldwork was completed. We thank Craig Magee and Meredith Townsend for detailed and thoughtful reviews and thank Dave Pollard for informal comments on a preprint version of this article, all of which helped us improve the manuscript.

\section{Author contributions}

DH designed the study and conducted the fieldwork with RR and MD. NF 'discovered' the dykes during a reconnaissance for her PhD. MH assisted with the petrographical and petrological analysis. DM provided regional context and supervision of MD. All authors have contributed to the manuscript text and figures.

\section{Data aVailability}

High-resolution orthomosaics can be found at https://doi.org/10.6084/m9.figshare.6849827.v2 [Healy 2018].

\section{COPYRight NOTICE}

(C) The Author(s) 2018. This article is distributed under the terms of the Creative Commons Attribution 4.0 International License, which permits unrestricted use, 
distribution, and reproduction in any medium, provided you give appropriate credit to the original author(s) and the source, provide a link to the Creative Commons license, and indicate if changes were made.

\section{REFERENCES}

Ágústsdóttir, T., J. Woods, T. Greenfield, R. G. Green, R. S. White, T. Winder, B. Brandsdóttir, S. Steinthórsson, and H. Soosalu (2016). "Strike-slip faulting during the 2014 Bárðarbunga-Holuhraun dike intrusion, central Iceland". Geophysical Research Letters 43.4, pp. 1495-1503. DOI: 10.1002/2015gl067423.

Andrews, S. D. and A. J. Hartley (2015). "The response of lake margin sedimentary systems to climatically driven lake level fluctuations: Middle Devonian, Orcadian Basin, Scotland". Sedimentology 62.6. Ed. by D. Ariztegui, pp. 1693-1716. Dor: $10.1111 / \mathrm{sed}$. 12200.

Baxter, A. N. and J. G. Mitchell (1984). "CamptoniteMonchiquite dyke swarms of Northern Scotland; Age relationships and their implications". Scottish Journal of Geology 20.3, pp. 297-308. DOI: 10 . 1144 / s jg20030297.

Brandsdóttir, B. and P. Einarsson (1979). "Seismic activity associated with the September 1977 deflation of the Krafla central volcano in northeastern Iceland". Journal of Volcanology and Geothermal Research 6.3-4, pp. 197-212. Dor: 10 . 1016/0377-0273 (79) 90001-5.

Brown, J. F. (1975). "Potassium-Argon evidence of a Permian age for the camptonite dykes: Orkney". Scottish Journal of Geology 11.3, pp. 259-262. DoI: 10.1144 / s jg11030259.

Burchardt, S. (2018). "Introduction to Volcanic and Igneous Plumbing Systems-Developing a Discipline and Common Concepts". Volcanic and Igneous Plumbing Systems. Elsevier, pp. 1-12. DoI: 10.1016/b9780-12-809749-6.00001-7.

Delaney, P. T. and D. D. Pollard (1981). Deformation of host rocks and flow of magma during growth of minette dikes and breccia-bearing intrusions near Ship Rock, New Mexico. Tech. rep. 102. USGPO.

Emeleus, C. H. and B. R. Bell (2005). The Palaeogene volcanic districts of Scotland. Vol. 3. British Geological Survey.

Ernst, R. E. and W. R. A. Baragar (1992). "Evidence from magnetic fabric for the flow pattern of magma in the Mackenzie giant radiating dyke swarm". Nature 356.6369, pp. 511-513. Dor: 10.1038/356511a0.

Fletcher, R. C. and D. D. Pollard (1981). "Anticrack model for pressure solution surfaces". Geology 9.9, p. 419. DOI: 10 . $1130 / 0091-7613$ (1981) $9<419$ : amfpss>2.0.co;2.

Galland, O., P. R. Cobbold, E. Hallot, J. de Bremond d'Ars, and G. Delavaud (2006). "Use of vegetable oil and silica powder for scale modelling of magmatic intrusion in a deforming brittle crust". Earth and
Planetary Science Letters 243.3-4, pp. 786-804. DoI: 10.1016/ j .epsl.2006.01.014.

Gudmundsson, A. (1983). "Form and dimensions of dykes in eastern Iceland". Tectonophysics 95.3-4, pp. 295-307. Dor: 10 . 1016/0040-1951 ( 83 ) 90074-4.

Healy, D. (2018). "Drone mosaics of Birsay dykes". Dor: $10.6084 / \mathrm{m} 9$. figshare.6849827.v2.

Hoek, J. D. (1994). "Mafic dykes of the Vestfold Hills, East Antarctica. An analysis of the emplacement mechanism of tholeiitic dyke swarms and of the role of dyke emplacement during crustal extension".

Johnson, R. B. (1961). "Patterns and Origin of Radial Dike Swarms Associated with West Spanish Peak and Dike Mountain, South-Central Colorado". Geological Society of America Bulletin 72.4, p. 579. DoI: 10.1130/ 0016-7606 (1961)72[579: paoord]2.0.co;2.

Jolly, R. and D. Sanderson (1995). "Variation in the form and distribution of dykes in the Mull swarm, Scotland". Journal of Structural Geology 17.11, pp. 1543-1557. Dor: 10.1016/0191-8141(95)00046g.

Kavanagh, J. L., A. J. Burns, S. H. Hazim, E. P. Wood, S. A. Martin, S. Hignett, and D. J. Dennis (2018). "Challenging dyke ascent models using novel laboratory experiments: Implications for reinterpreting evidence of magma ascent and volcanism". Journal of Volcanology and Geothermal Research 354, pp. 87-101. Dor: $10.1016 /$ j . jvolgeores . 2018.01.002.

Kimbell, G. and J. Williamson (2016). "A gravity interpretation of the Orcadian Basin area". Energy and Marine Geoscience Programme Commissioned Report CR/16/034, pp. 1-41.

Maccaferri, F., M. Bonafede, and E. Rivalta (2011). "A quantitative study of the mechanisms governing dike propagation, dike arrest and sill formation". Journal of Volcanology and Geothermal Research 208.1-2, pp. 39-50. Dor: 10.1016/ j . jvolgeores . 2011.09. 001.

Magee, C., C. A.-L. Jackson, and N. Schofield (2014). "Diachronous sub-volcanic intrusion along deepwater margins: insights from the Irish Rockall Basin”. Basin Research 26.1, pp. 85-105. Dor: 10 . 1111/bre. 12044.

Magee, C., J. Muirhead, N. Schofield, R. J. Walker, O. Galland, S. Holford, J. Spacapan, C. A.-L. Jackson, and W. McCarthy (2018). "Structural signatures of igneous sheet intrusion propagation". Journal of Structural Geology. DoI: 10.1016/ j . jsg.2018.07 . 010.

Marshall, J. E. A., J. F. Brown, and S. Hindmarsh (1985). "Hydrocarbon source rock potential of the Devonian rocks of the Orcadian Basin". Scottish Journal of Geology 21.3, pp. 301-320. Dor: 10.1144/s jg21030301.

Mauldon, M., W. Dunne, and M. Rohrbaugh (2001). "Circular scanlines and circular windows: new tools for characterizing the geometry of fracture traces". Journal of Structural Geology 23.2-3, pp. 247-258. Dor: 10.1016/s0191-8141(00)00094-8. 
McClay, M. G. Norton, P. Coney, and G. H. Davis (1986). "Collapse of the Caledonian orogen and the Old Red Sandstone". Nature 323.6084, pp. 147-149. DoI: $10.1038 / 323147 \mathrm{a} 0$.

Nicholson, R. and D. Pollard (1985). "Dilation and linkage of echelon cracks". Journal of Structural Geology 7.5, pp. 583-590. DoI: $10.1016 / 0191-8141$ (85) 90030-6.

Parnell, J. (1985). "Hydrocarbon source rocks, reservoir rocks and migration in the Orcadian Basin". Scottish Journal of Geology 21.3, pp. 321-335. Dor: 10.1144 / s jg21030321.

Poland, M. P., W. P. Moats, and J. H. Fink (2008). "A model for radial dike emplacement in composite cones based on observations from Summer Coon volcano, Colorado, USA". Bulletin of Volcanology 70.7, pp. 861-875. Dor: 10.1007/s00445-007-0175-9.

Pollard, D. D., O. H. Muller, and D. R. Dockstader (1975). "The Form and Growth of Fingered Sheet Intrusions". Geological Society of America Bulletin 86.3, p. 351. Dor: 10 . $1130 / 0016-7606$ ( 1975 ) 86<351: tfagof $>2.0$. co; 2 .

Pollard, D. D. and M. R. Townsend (2018). "Fluid-filled fractures in Earth's lithosphere: Gravitational loading, interpenetration, and stable height of dikes and veins". Journal of Structural Geology 109, pp. 38-54. Dor: $10.1016 / \mathrm{j}$. jsg. 2017.11.007.

Rickwood, P. (1990). "The anatomy of a dyke and the determination of propagation and magma flow directions". Mafic dykes and emplacement mechanisms. Balkema, Rotterdam 81, p. 100.

Rivalta, E., B. Taisne, A. Bunger, and R. Katz (2015). "A review of mechanical models of dike propagation: Schools of thought, results and future directions". Tectonophysics 638, pp. 1-42. Dor: $10.1016 / \mathrm{j}$. tecto . 2014.10.003.

Rock, N. M. (1983). The Permo-Carboniferous camptonite-monchiquite dyke-suite of the Scottish Highlands and Islands: distribution, field and petrological aspects. HM Stationery Office.

Rubin, A. M. and D. D. Pollard (1987). "Origins of bladelike dikes in volcanic rift zones". US Geological Survey Professional Paper 1350.2, pp. 1449-1470.

Rubin, A. M. (1995). "Propagation of Magma-Filled Cracks". Annual Review of Earth and Planetary Sciences 23.1, pp. 287-336. Dor: 10.1146/annurev. ea . 23.050195.001443.

Ryan, M. P. (1988). "The mechanics and threedimensional internal structure of active magmatic systems: Kilauea Volcano, Hawaii". Journal of Geo- physical Research: Solid Earth 93.B5, pp. 4213-4248. DOI: 10. 1029/ jb093ib05p04213.

Schofield, N., L. Heaton, S. P. Holford, S. G. Archer, C. A.-L. Jackson, and D. W. Jolley (2012). "Seismic imaging of 'broken bridges': linking seismic to outcrop-scale investigations of intrusive magma lobes". Journal of the Geological Society 169.4, pp. 421-426. Dor: 10.1144/0016-76492011-150.

Staudigel, H., J. Gee, L. Tauxe, and R. J. Varga (1992). "Shallow intrusive directions of sheeted dikes in the Troodos ophiolite: Anisotropy of magnetic susceptibility and structural data". Geology 20.9, p. 841. Dor: 10. $1130 / 0091-7613$ ( 1992 ) 020<0841: sidosd $>2$. 3 . co;2.

Strachan, R. A. (2003). "The metamorphic basement geology of Mainland Orkney and Graemsay". Scottish Journal of Geology 39.2, pp. 145-149. Dor: 10.1144/ sjg39020145.

Townsend, M. R. (2018). "Modeling Thermal Pressurization Around Shallow Dikes Using TemperatureDependent Hydraulic Properties: Implications for Deformation Around Intrusions". Journal of Geophysical Research: Solid Earth 123.1, pp. 311-323. Dor: 10 . 1002/2017 jb014455.

Townsend, M. R., D. D. Pollard, and R. P. Smith (2017). "Mechanical models for dikes: A third school of thought". Tectonophysics 703-704, pp. 98-118. DoI: $10.1016 /$ j . tecto. 2017.03 .008 .

Townsend, M., D. D. Pollard, K. Johnson, and C. Culha (2015). "Jointing around magmatic dikes as a precursor to the development of volcanic plugs". Bulletin of Volcanology 77.10. DoI: 10.1007/s00445-015-0978$\mathrm{z}$.

USGS Hawaiian Volcano Observatory (2018). Kilauea: Maps. URL: https : / / volcanoes. usgs gov / volcanoes/kilauea/multimedia_maps.html (visited on 06/01/2018).

Wall, M., J. Cartwright, R. Davies, and A. McGrandle (2010). "3D seismic imaging of a Tertiary Dyke Swarm in the Southern North Sea, UK". Basin Research 22.2, pp. 181-194. DoI: $10.1111 / \mathrm{j} .1365-$ 2117.2009.00416.x.

Walsh, J., J. Watterson, W. Bailey, and C. Childs (1999). "Fault relays, bends and branch-lines". Journal of Structural Geology 21.8-9, pp. 1019-1026. Dor: 10 . 1016/s0191-8141(99)00026-7.

Wheeler, J., R. G. Park, H. R. Rollinson, and A. Beach (2010). "The Lewisian Complex: insights into deep crustal evolution". Geological Society, London, Special Publications 335.1, pp. 51-79. Dor: 10.1144/sp335.4. 